Nevada

Environmental

Restoration

Project

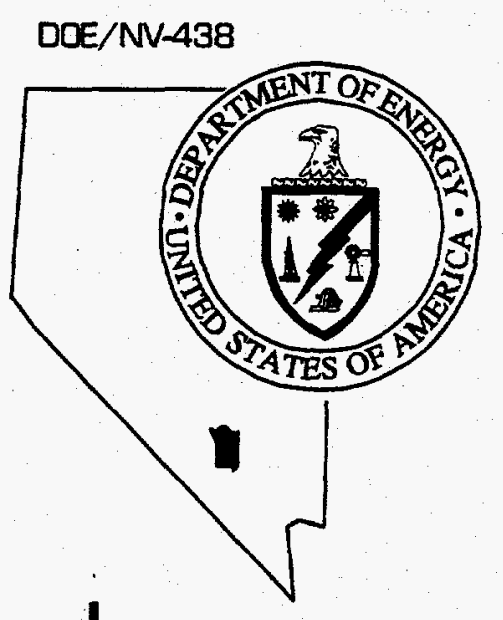

\title{
Resource Conservation and
}

Recovery Act

Industrial Site Environmental

Restoration Site

Characterization Plan os TI

\section{Area 6 Decontamination Pond Facility}

Controlled Copy No.: Tho

Revision: 1

August 1996

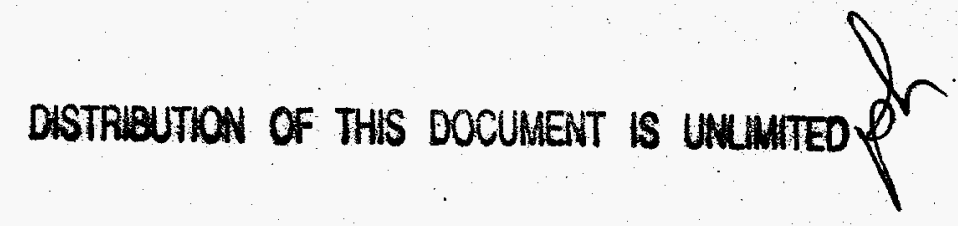

MASTER

Environmental Restoration

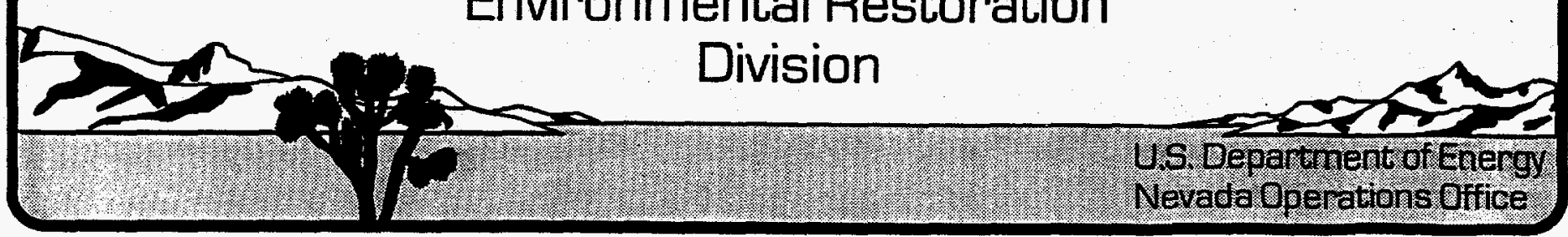




\section{DISCLAMMER}

This repor was prepared as an account of work sponsored by an agency of the United States Goverament Neither the United States Governmeat nor any ageacy thereof, nor any of their employees, makes any warranty, express or implied, or assumes any legal liability or responsibility for the aceuracy, completedess, or usefulness of any information, apparatus, product, or process disclosed, or represents that its use would not infringe privately owned rights. Reference herein to any specific commercial product, process, or service by trade aame, trademart, tmanufacturer, or otherwise does not necessarily constitute or imply its endorsement, recommendation. or favoring by the United States Governmeot or any agency thereof. The views and opinions of authors expressed berein do not aecescarily state or reflect those of the. United States Government or any agency thereof. 


\section{DISCLAIMER}

Portions of this document may be illegible in electronic image products. Images are produced from the best available original document. 


\section{RESOURCE CONSERVATION AND RECOVERY ACT INDUSTRIAL SITE ENVIRONMENTAL RESTORATION SITE CHARACTERIZATION PLAN}

\section{AREA 6 DECONTAMINATION POND FACILITY}

DOE Nevada Operations Office

Las Vegas, Nevada

Controlled Copy $N$.

Revision: 1

August 1996 


\section{RESOURCE CONSERVATION AND RECOVERY ACT INDUSTRIAL SITE ENVIRONMENTAL RESTORATION SITE CHARACTERIZATION PLAN}

AREA 6 DECONTAMINATION POND FACILITY

Approved by: $\frac{\text { Sabilu } \operatorname{Cur} \pitchfork s}{\text { Sabine Curtis, Manager, }}$ Industrial Sites Subproject

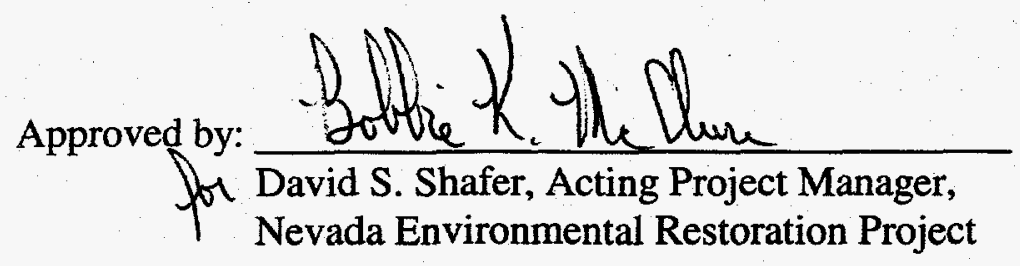
Nevada Environmental Restoration Project
Date: $\quad 8 / 12 / 96$ Date: $8 / 12 / 96$ 


\section{Table of Contents}

List of Figures $\ldots \ldots \ldots \ldots \ldots \ldots \ldots \ldots \ldots \ldots \ldots \ldots \ldots \ldots \ldots \ldots \ldots \ldots \ldots$

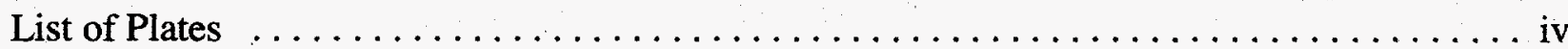

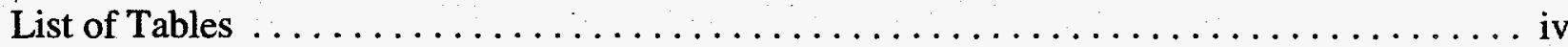

List of Acronyms and Abbreviations $\ldots \ldots \ldots \ldots \ldots \ldots \ldots \ldots \ldots \ldots \ldots \ldots \ldots \ldots \ldots \ldots \ldots$

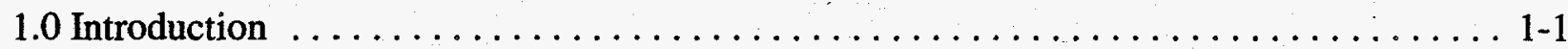

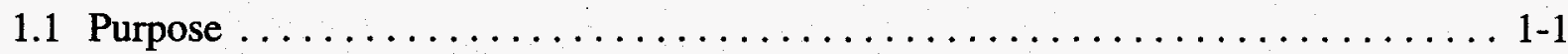

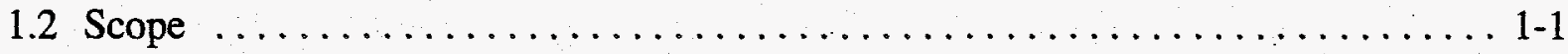

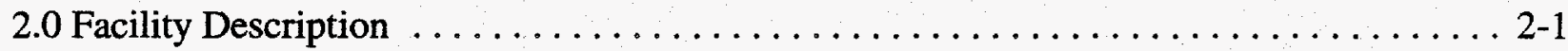

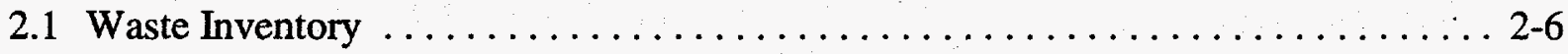

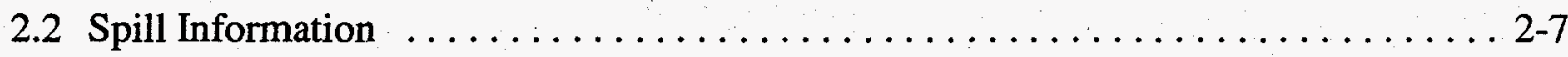

2.3 Previous Characterization Plans and Activities $\ldots \ldots \ldots \ldots \ldots \ldots \ldots \ldots \ldots$

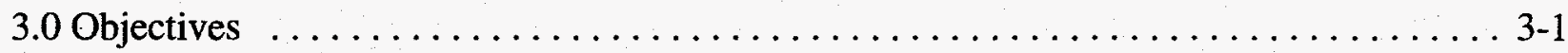

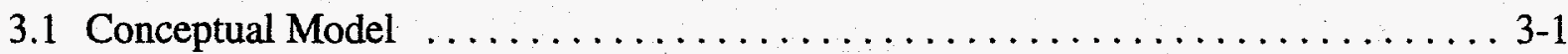

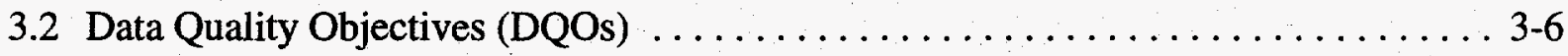

3.3 Technical Approach $\ldots \ldots \ldots \ldots \ldots \ldots \ldots \ldots \ldots \ldots \ldots \ldots \ldots \ldots \ldots \ldots \ldots \ldots \ldots$

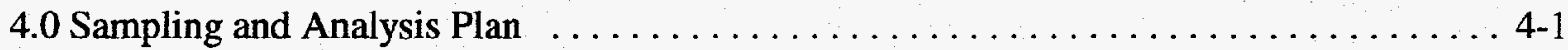

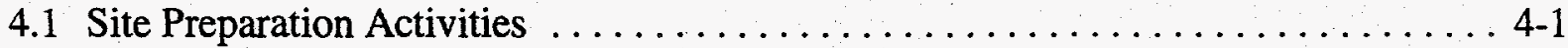

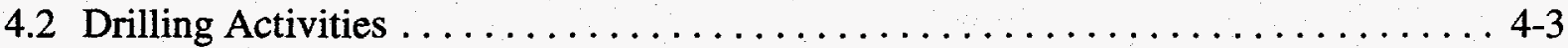

4.3 Sampling Activities $\ldots \ldots \ldots \ldots \ldots \ldots \ldots \ldots \ldots \ldots \ldots \ldots \ldots \ldots \ldots \ldots \ldots$

4.4 Sample Analysis $\ldots \ldots \ldots \ldots \ldots \ldots \ldots \ldots \ldots \ldots \ldots \ldots \ldots \ldots \ldots \ldots \ldots .5$

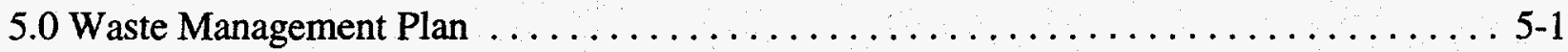

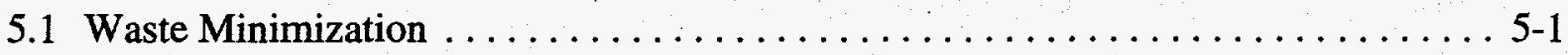

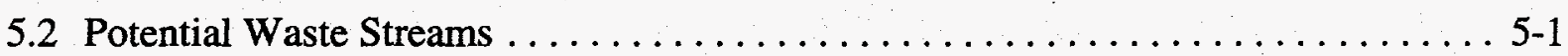

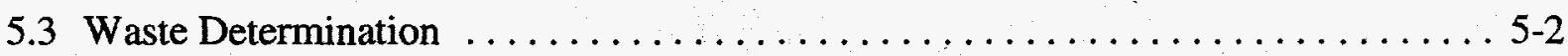

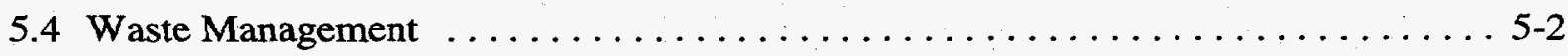




\section{Table of Contents (Continued)}

6.0 Reporting $6-1$

7.0 References $7-1$

Appendix A - Environmental Setting

A-1

Appendix B - Results of Previous Evaluatioris B-1 


\section{List of Figures}

Number

Title

Page

2-1 Location of the Nevada Test Site

$2-2$

2-2 Location of the Area 6 Decontamination Pond Facility

2-3 Area 6 Waste Management Facilities at the Nevada Test Site

$2-4$

2-4 Topographic Site Plan Area 6 Decontamination Pond Facility

3-1 Map View of the Conceptual Model for the Area 6 Decontamination

Pond Facility

3-2 Cross-sectional View of the Conceptual Model for the Area 6 Decontamination Pond Facility

4-1 Possible Configuration of Access Ramp, Area 6 Decontamination

Pond Facility

4-2 . Planned Soil Boring Locations, Area 6 Decontamination Pond Facility . . . . . . . 4-4

B-1 Exploratory Borehole Locations Near the Area 6 Decontamination Pond Facility

B-2 1994 Preliminary Soil Sample Locations, Area 6 Decontamination

Pond Facility

B-3 Surveyed Site Grid Area 6 Decontamination Pond Facility

B-4 March 1996 Surface Radiation Survey Results, Area 6 Decontamination

Pond Facility

B-5 March 1996 Surface Soil Sample Locations, Area 6 Decontamination Pond Facility B-14 


\section{List of Plates}

Plate 1 - Waste Management Strategy Decision Process, Area 6 Steam Decontamination Pond Facility

\section{List of Tables}

Number

Title

Page

2-1 Cleaning Agents Used Prior to November 1988 at Buildings 6-605 and 6-607 . . 2-6

2-2 Cleaning Agents Used Since November 1988 at Buildings 6-605 and 6-607 . . . 2-7

4-1 Characterization Analytical Methods . . . . . . . . . . . . . .

B-1 Yearly Radiological Monitoring Result Averages $\ldots \ldots \ldots \ldots \ldots \ldots \ldots \ldots \ldots$ B-1

B-2 Analytical Results for Water Samples, June $1986 \ldots \ldots \ldots \ldots \ldots \ldots \ldots \ldots$. . . . . . .

B-3 Summary of Laboratory Results from the 1990 Preliminary Evaluation . . . . . . . B-6

B-4 Detected Constituents of Concern for the 1994 Preliminary Soil Sampling of the Area 6 Decontamination Pond Facility . . . . . . . . . . . . . . . . . B-9

B-5 March 1996 Preliminary Evaluation Analytical Methods . . . . . . . . . . B-16

B-6 Detected Constituents of Concern for the 1996 Preliminary Surface Soil Sampling of the Area 6 Decontamination Pond Facility 


\section{List of Acronyms and Abbreviations}

\begin{tabular}{|c|c|}
\hline Am-241 & Americium-241 \\
\hline APHA & American Public Health Association \\
\hline ASTM & American Society for Testing and Materials \\
\hline bgs & Below ground surface \\
\hline $\mathrm{Bi}-212 / 214$ & Bismuth-212/124 \\
\hline $\mathrm{BN}$ & Bechtel Nevada \\
\hline CFR & Code of Federal Regulations \\
\hline $\mathrm{cm}$ & Centimeter(s) \\
\hline Co-60 & Cobalt- 60 \\
\hline $\mathrm{COC}$ & Contaminant(s) of Concern \\
\hline $\mathrm{cpm}$ & Count(s) per minute \\
\hline CRDL & Contract-required detection limit \\
\hline Cs-137 & Cesium-137 \\
\hline DOE & U.S. Department of Energy \\
\hline DOE/NV & U.S. Department of Energy, Nevada Operations Office \\
\hline DOT & U.S. Department of Transportation \\
\hline DPF & Area 6 Decontamination Pond Facility \\
\hline DQO & Data quality objective(s) \\
\hline EIS & Environmental Impact Statement \\
\hline EM & Electromagnetic Induction \\
\hline EPA & U.S. Environmental Protection Agency \\
\hline ERD & Environmental Restoration Division \\
\hline FID & Flame ionization detector \\
\hline $\mathrm{ft}$ & Foot (feet) \\
\hline gal & Gallon(s) \\
\hline IDW & Investigation-derived waste \\
\hline in. & $\operatorname{Inch}(\mathrm{es})$ \\
\hline IT & IT Corporation \\
\hline $\mathrm{K}-40$ & Potassium-40 \\
\hline kg & Kilogram(s) \\
\hline km & Kilometer(s) \\
\hline LDR & Land disposal restriction \\
\hline LLW & Low-level radioactive waste \\
\hline $\mathrm{m}$ & Meter(s) \\
\hline $\mathrm{m}^{3}$ & Cubic meter(s) \\
\hline
\end{tabular}




\section{List of Acronyms and Abbreviations (Continued)}

\begin{tabular}{|c|c|}
\hline MCLs & Maximum contaminant level(s) \\
\hline $\mathrm{mg} / \mathrm{kg}$ & Milligram(s) per kilogram \\
\hline $\mathrm{mg} / \mathrm{L}$ & Milligram(s) per liter \\
\hline $\mathrm{mi}$ & $\operatorname{Mile}(s)$ \\
\hline NAC & Nevada Administrative Code \\
\hline $\mathrm{NaI}$ & Sodium Iodide \\
\hline NDEP & Nevada Division of Environmental Protection \\
\hline NTS & Nevada Test Site \\
\hline PARCC & Precision, accuracy, representativeness, comparability, and completeness \\
\hline PB-212/214 & Lead-212/214. \\
\hline PCBs & Polychlorinated biphenyl(s) \\
\hline POC & Performance Objective for Certification \\
\hline PID & Photoionization detector \\
\hline PPE & Personal protective equipment \\
\hline ppm & Part(s) per million \\
\hline $\mathrm{Pu}$ & Plutonium \\
\hline QA & Quality assurance \\
\hline QC & Quality control \\
\hline RA-226/228 & Radium-226/228 \\
\hline RCRA & Resource Conservation and Recovery Act \\
\hline REECo & Reynolds Electrical \& Engineering Co., Inc. \\
\hline SOW & Soil/oil/water \\
\hline SVOC & Semivolatile organic compound(s) \\
\hline $\mathrm{TC}$ & Toxicity characteristic \\
\hline $\mathrm{Tl}-208$ & Thallium-28 \\
\hline TPH & Total petroleum hydrocarbon(s) \\
\hline TRU Pad & Area 5 Radioactive Waste Management Site Transuranic Waste Storage Pad \\
\hline TSCA & Toxic Substances Control Act \\
\hline VOC & Volatile organic compound(s) \\
\hline$\mu \mathrm{Ci} / \mathrm{mL}$ & Microcurie(s) per milliliter \\
\hline$\mu \mathrm{g} / \mathrm{kg}$ & Microgram(s) per kilogram \\
\hline
\end{tabular}




\subsection{Introduction}

\subsection{Purpose}

This plan presents the strategy for the characterization of the Area 6 Decontamination Pond Facility (DPF) at the Nevada Test Site (NTS) which will be conducted for the U.S. Department of Energy, Nevada Operations Office (DOE/NV), Environmental Restoration Division (ERD). The objectives of the planned activities are to:

- Obtain sufficient, sample analytical data from which further assessment, remediation, and/or closure strategies may be developed for the site.

- Obtain sufficient, sample analytical data for management of investigation-derived waste (IDW).

All references to regulations contained in this plan are to the versions of the regulations that are current at the time of publication of this plan.

\subsection{Scope}

The scope of the characterization may include surface radiation survey(s), surface soil sampling, subsurface soil boring (i.e., drilling), and sampling of soil in and around the pond; in situ sampling of the soil within subsurface soil borings; and sample analysis for both site characterization and waste management purposes. 


\subsection{Facility Description}

The DPF is located in Area 6 at the NTS, a United States Department of Energy (DOE) research and development facility in Nye County, Nevada. The NTS is approximately 105 kilometers $(\mathrm{km})$ (65 miles [mi]) northwest of Las Vegas, the major population center in the area (Figure 2-1). Area 6 is in the southern part of Yucca Flat area of the NTS. Regional and local topography, soil types, stratigraphy, surface water features, and groundwater which might affect the migration of contaminants at the site are discussed in Appendix A.

The DPF was used for the disposal of untreated liquid effluent discharged from Buildings 6-605 (Decontamination Facility) and 6-607 (Industrial Laundry) and is located southeast of the intersection of Road 6-05 and Mercury Road 6-01 (i.e., Mercury Highway) (Figures 2-2 and 2-3). The DPF was constructed and became operational in 1979. It is a square unit, approximately 60 meters $(\mathrm{m})$ (200 feet [ft]) long on each interior side, $1.5 \mathrm{~m}(5 \mathrm{ft})$ deep, and has a maximum capacity of approximately 4,500 cubic meters $\left(\mathrm{m}^{3}\right)(1,180,000$ gallons [gal]) (Figure 2-4). A discharge pipe enters the pond on the southwest side approximately $0.3 \mathrm{~m}(1 \mathrm{ft})$ above the bottom of the pond. The pond is unlined and surrounded by an earthen berm on all four sides which have a two-to-one grade. Access to the DPF is restricted by a chain-link fence posted with radiation warning signs (DOE, 1994a).

Effluent from Building 6-605 and Building 6-607 was piped northeast to the DPF, a distance of approximately $180 \mathrm{~m}(600 \mathrm{ft})$. Heavy equipment and critical tolerance instruments used in weapons tests were processed in Building 6-605 to remove any radioactive contamination. The equipment was taken into the decontamination bay, an area resembling a car wash with a high ceiling, manually brushed with degreasers, caustic or acid solutions, and detergents and then spray-washed with hot water under high pressure. Drill pipes were immersed in a weak caustic or acidic bath, cleaned, and rinsed. The wash water was collected in floor drains that run along the length and width of the facility. To remove heavy particulates and viscous liquids from the rinsates, the floor drains discharged through a sand filter/separator and an oil separator. Radioactively contaminated site worker clothing (e.g., coveralls, gloves, and boot covers) were decontaminated using standard industrial water softeners and laundry detergents in three washers at Building 6-607 (REECo, 1991a). The effluent from both of these source facilities was discharged to the DPF. 


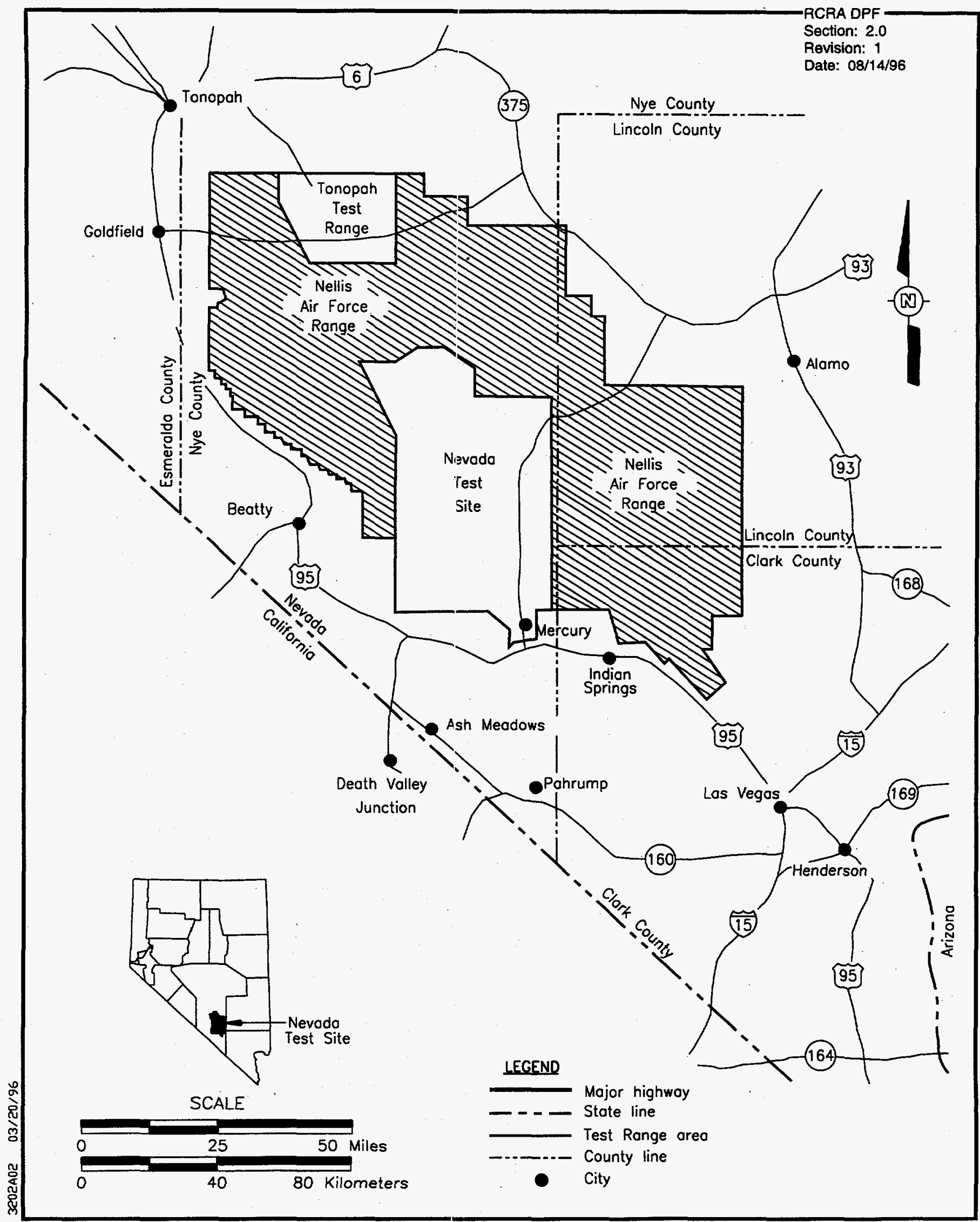

Figure 2-1

Location of the Nevada Test Site 


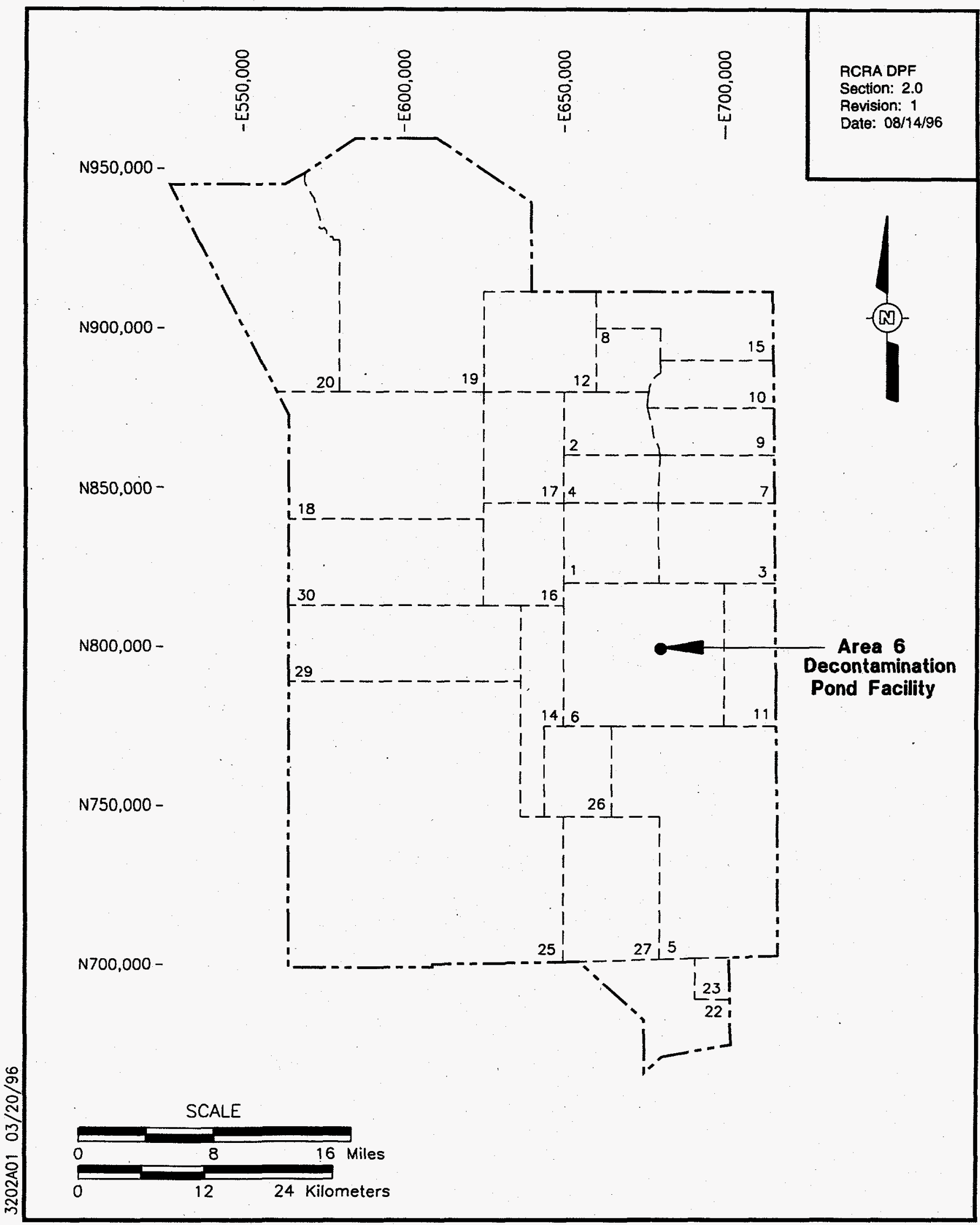

Figure 2-2

Location of the Area 6 Decontamination Pond Facility 
OfIS 7SOL epenan aYt te

sa!f!!)

$\varepsilon-2$ อมกต!

juawpunodu! әэojuns

วצ0า Doonर

ठNJปรา

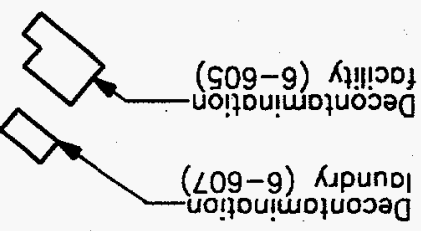

(2)
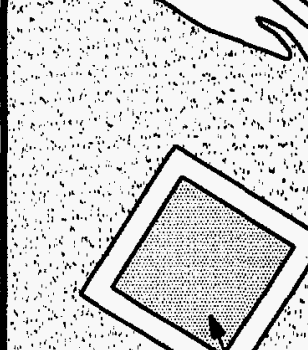

(-9)

$(z-d\rfloor า-9)$ रो!ा!

puod uolpoulwofuosag

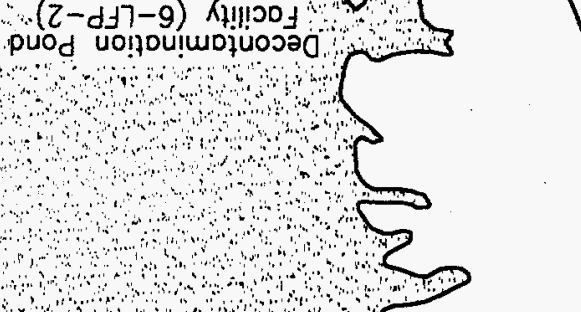

a

4

S

(1)

(Lip)
ว407 Dosr

(Ro)
ayo7 Dosn
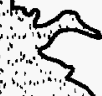

2
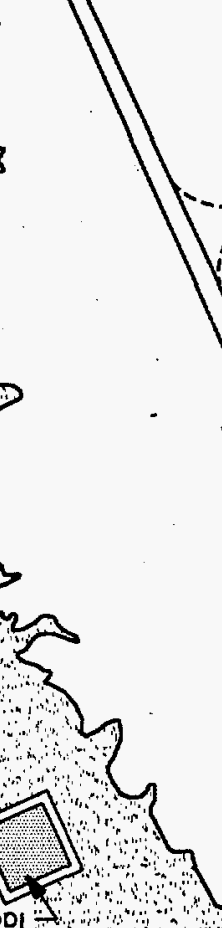

,
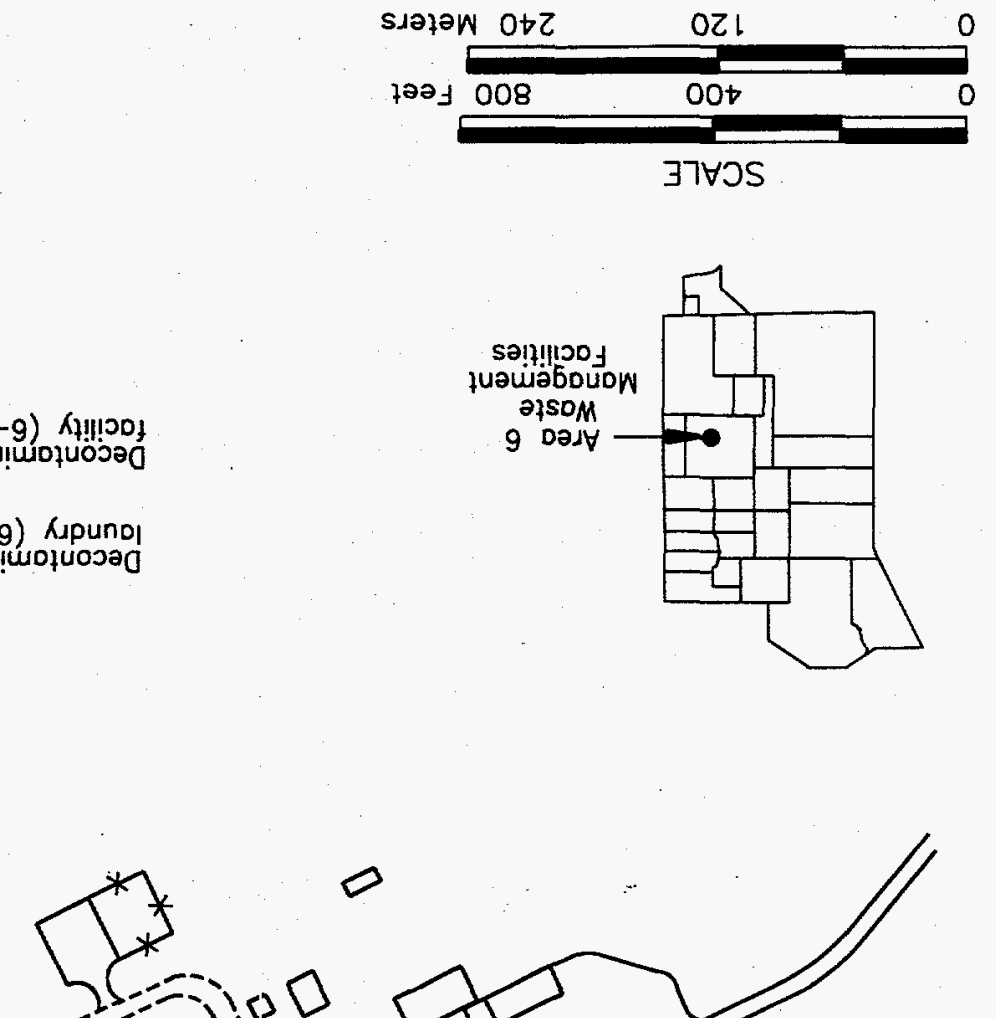

$\exists 7 \forall 0 S$
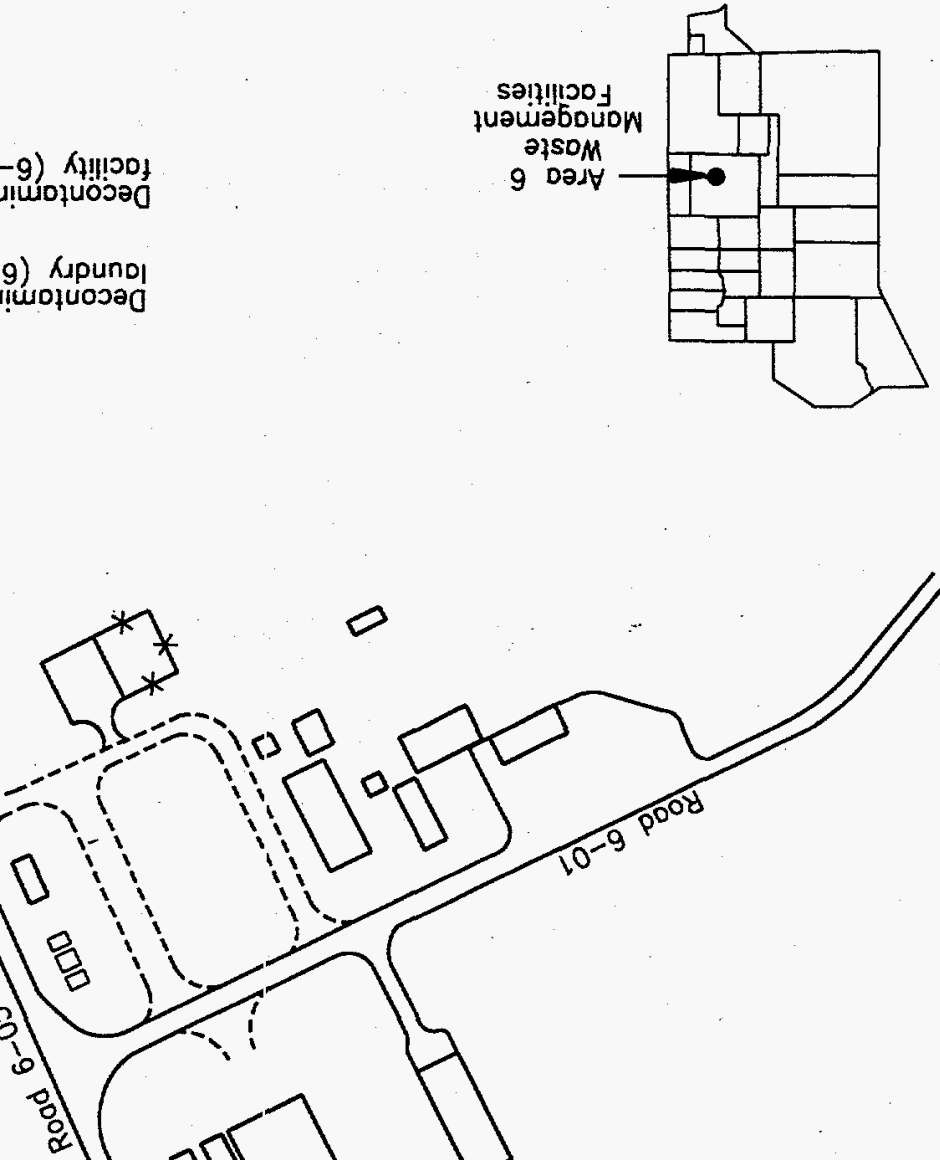

i!

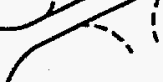

$4 \div$ !
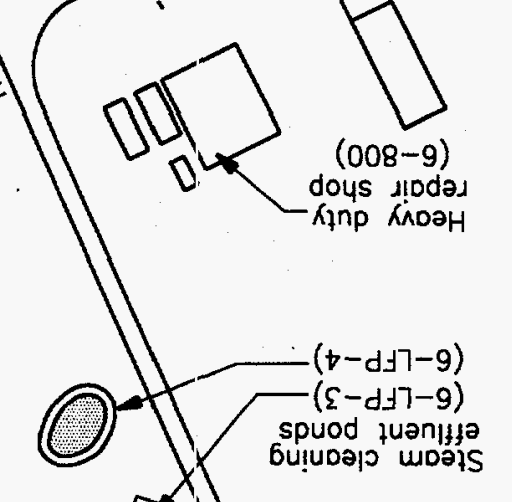

D. (008-9)

dous liodad
Kinp KnOOH

$\downarrow$ :uolsiney

0.2 :uonves

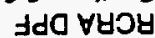

260Mas
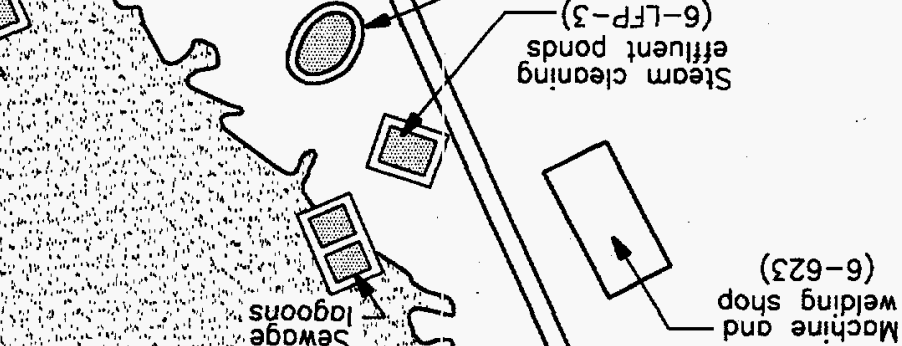


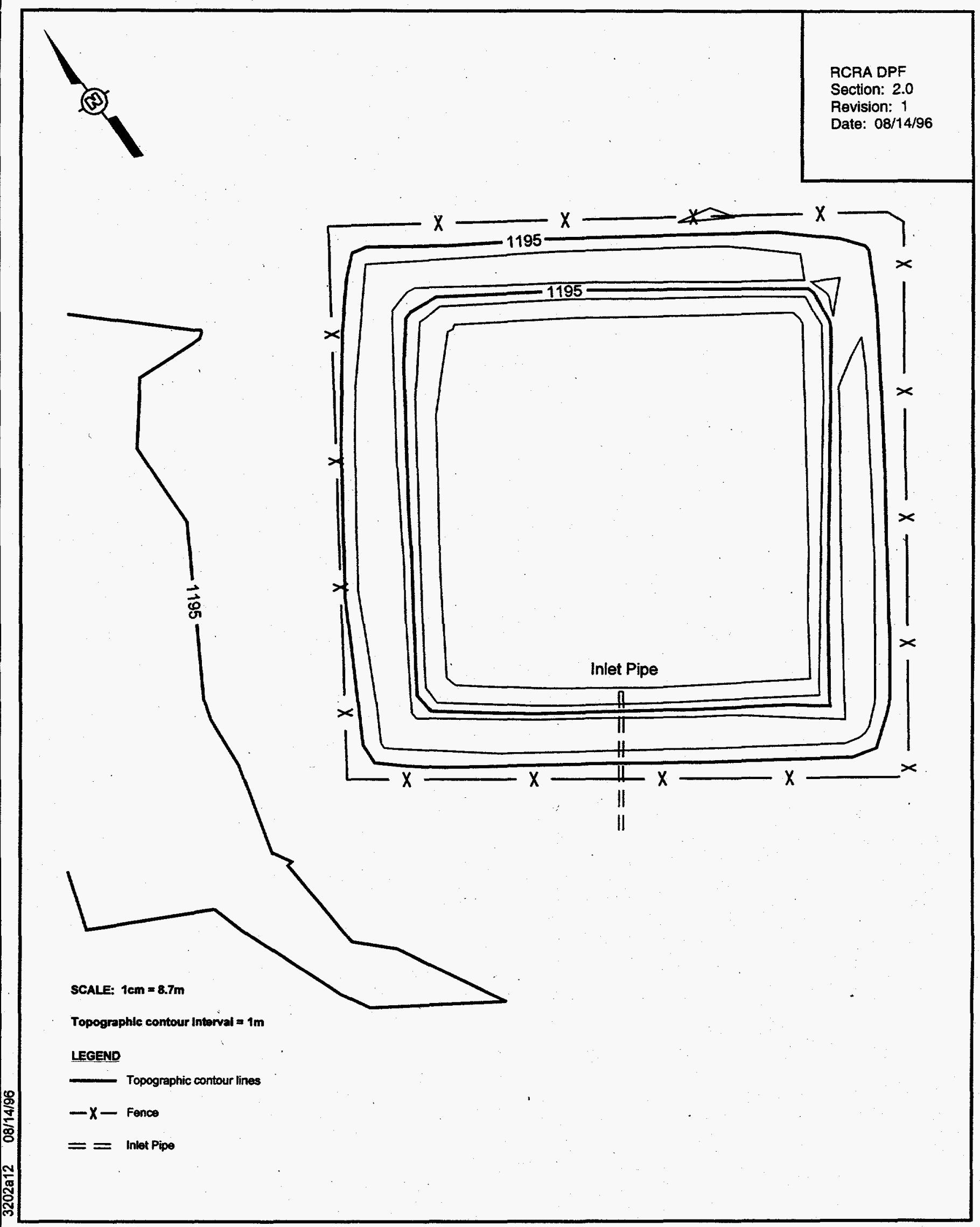

Figure 2-4

Topographic Site Plan

Area 6 Decontamination Pond Facility 
Since November 1988, process knowledge, administrative controls, and employee training have precluded the discharge of Resource Conservation and Recovery Act (RCRA) regulated materials to the DPF (REECo, 1988; IT, 1992). The volume of effluent annually discharged to the DPF was dependent upon the number of weapons tests conducted each year. The quantity of equipment and clothing requiring decontamination (and the volume of effluent generated) was directly proportional to the number of weapons tests performed at the NTS. In a single year (i.e., 1986), an estimated total of $14,000 \mathrm{~m}^{3}$ ( 3.6 million gallons) of effluent were discharged to the pond (DOE, 1988b).

\subsection{Waste Inventory}

In the past, a wide variety of materials have been used to decontaminate equipment in Buildings 6-605 and 6-607, including RCRA-regulated acids, bases, and solvents (REECo, 1991a; IT, 1992). Table 2-1 provides a list of known cleaning agents in use at Buildings 6-605 and 6-607.

\begin{tabular}{||l||}
\hline Aluminum hydroxide cleaner \\
Benzenes (chlorinated) \\
2-Butoxyethanol \\
Hydrocarbon solvents \\
Hydrochloric acid \\
Isopropyl alcohol \\
Laundry water softener \\
Methyl alcohol \\
Methylene chloride \\
Organic acids \\
Petroleum naphtha \\
Phenols \\
Rust remover \\
Sodium bisulfate \\
Sodium hydroxide \\
Sodium hypochlorite \\
Sodium and potassium hydroxides and sulfides \\
Tall oil soap \\
Xylene (Shell) \\
Water-based detergents \\
\hline
\end{tabular}

\footnotetext{
${ }^{a}$ Source: DOE, 1989
} 
Table 2-2

\section{Cleaning Agents Used Since November 1988} at Buildings $6-605$ and $6-607^{a}$

\begin{tabular}{||l|c|}
\hline \multicolumn{1}{|c|}{ Compound } & Estimated Annual Usage (Gallons) \\
\hline Bleach & 15 \\
Soft \& Sour & 30 \\
Kee Whiz Degreaser & 15 \\
152A Detergent & 20 \\
215 Rust Remover & 210 \\
Citrikleen & 210 \\
Caustic Hasa & 1,980 \\
\hline
\end{tabular}

asource: DOE, 1989

prior to the 1988 institution of administrative controls prohibiting the use of RCRA-regulated materials. Table 2-2 provides a list of the non-RCRA-regulated materials presently used at the facilities. In addition to cleaning agents, the pond also received lead, oil, grease, lithium, and sulfur from drill-pipe dope washed at Building 6-605 in addition to mixed fission products (including cesium, plutonium, and tritium), low-level waste, and other radioactive constituents. The DPF was removed from service and all known access lines were plugged and rerouted to above-ground tanks in 1992 (DOE, 1994a).

\subsection{Spill Information}

Two spills from the DPF have been reported. In 1990, a clay discharge pipe from Building 6-605 to the pond broke as a result of a trenching operation near Road 6-05, releasing an unknown amount of effluent to the subsurface soil. The pipe was repaired, but no information on the volume or chemicals of potential concern released is available (DOE, 1994a).

On March 3, 1991, the earthen berm on the northwest side of the DPF was reportedly breached due to an intense rainstorm and heavy winds, spilling effluent onto the playa (REECo, 1991a). A small erosional channel approximately $9 \mathrm{~m}$ (30 ft) in length, 15 centimeters $(\mathrm{cm})(6$ inches [in.])

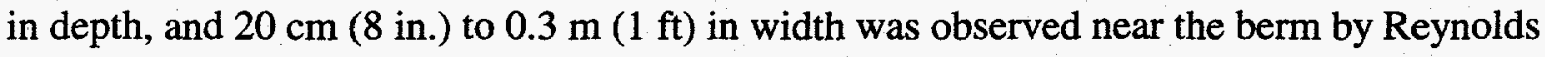
Electrical \& Engineering Company, Inc. (REECo), Environmental Compliance Office staff the following day. No erosion beyond $9 \mathrm{~m}(30 \mathrm{ft})$ of the playa was observed. Discontinuous wet zones were observed along the length of the berm and on the opposite side of the pond. No free water was observed on the playa. The extent of the affected area is estimated to be 60 ' $\mathrm{m}(200 \mathrm{ft})$ square and is delineated by rebar placed in the lake bed. No samples of either the pond water or 
the potentially impacted soil outside of the DPF were obtained for analysis at the time of the spill.

\subsection{Previous Characterization Plans and Activities}

To date, at least one draft and one final characterization plan have been produced for the DPF (DOE, 1993; DOE, 1994a). In addition, a closure plan which also addressed characterization of the site, was produced in 1989 and revised in 1991 (DOE, 1989; DOE, 1991). Each subsequent plan was written to address comments from the Nevada Division of Environmental Protection (NDEP) or DOE about previous plans and changing characterization methods, strategies, and philosophies. None of the previous characterization plans was approved by both the DOE and the NDEP; subsequently, no characterization work was performed under the guidance of the plans. This plan incorporates and in some cases refines process knowledge presented in the earlier plans. The current plan is intended to supersede all previous characterization plans, and it contains some significant changes in the approach to characterization planning and implementation.

Previous characterization activities at the DFF have involved the following:

- Archival information has been gathered from available sources to help define a basic understanding of the processes that were conducted at the DPF and associated facilities as well as the waste management practices that led to the designation of this site as a potential, RCRA-regulated, waste management unit.

- Preliminary site investigations were conducted to obtain useful information for the design of the site characterization plan and development of conceptual models of potential contaminant migration at the site in order to optimize the cost-effectiveness of the characterization activities.

Limited preliminary evaluations of the pond water and sediments have been conducted at the DPF. An NTS environmental monitoring program required that water samples be collected from the DPF for radioactivity analyses. Between 1985 and 1990, analysis of pond water samples indicated average tritium levels between $7.5 \times 10^{-7}$ and $3.9 \times 10^{-6}$ microcuries per milliliter $(\mu \mathrm{Ci} / \mathrm{mL})$, gross beta levels between $8.6 \times 10^{-8}$ and $3.6 \times 10^{-7} \mu \mathrm{Ci} / \mathrm{mL}$, and plutonium (Pu-239 or Pu-239+240) levels between $5.2 \times 10^{-12}$ and $3.9 \times 10^{-10} \mu \mathrm{Ci} / \mathrm{mL}$ (REECo, 1986, 1988, 1989, 1990, and 1991b). 
In June 1986, as part of the NTS Mixed Waste Assessment Summary (Bicker, 1986), the western-most shore of the DPF, $0.3 \mathrm{~m}$ (1 ft) from the inlet pipe, was sampled and analyzed for the complete set of semivolatile organic compounds (SVOC), volatile organic compounds (VOC), inorganic metals listed in 40 CFR 122, and radioactive constituents. The results of the 1986 pond water evaluation indicated that the water contained very low concentrations of VOCs, metals, and radionuclides, all below applicable regulatory action levels (i.e., maximum contaminant levels [MCLs] from Title 40 CFR \$141). One SVOC, bis(2-ethylhexyl)phthalate, was detected at levels significantly above the MCL (Bicker, 1986; DOE, 1988a). However, bis(2-ethylhexyl)phthalate is considered to be a common laboratory or sampling method contaminant and is unlikely to actually be a contaminant at the site, based on process knowledge and other preliminary sampling results. Additional analytical results are provided in Appendix B.

A 1990 REECo sampling event involved the collection of soil and pond liquid samples in conjunction with exploratory borehole drilling in the area of the DPF. The 1990 preliminary evaluation of subsurface soil and potentially perched groundwater in the vicinity of the DPF indicated the presence of acetone and methylene chloride at low concentrations (200 to 342 micrograms per kilogram $[\mu \mathrm{g} / \mathrm{kg}]$ and 42 to $116 \mu \mathrm{g} / \mathrm{kg}$ respectively). However, at these concentrations, it is likely that these VOCs are the result of laboratory contamination. This conclusion is further supported by the presence of methylene chloride in method blanks (REECo, 1991a). Perched, shallow groundwater was not encountered during this effort.

A resistivity investigation was conducted by Engineering-Science in 1990.(ES, 1990) for REECo, and a geophysical survey was conducted by IT Corporation (IT) in 1994 (IT, 1996). With only limited information available about the subsurface stratigraphy and soil conditions in the vicinity of the site, the results of these remote sensing evaluations are generally inconclusive (i.e., it is uncertain whether subsurface anomalies indicate the changes in subsurface stratigraphy, the presence of saturated zones, shallow perched groundwater, or other features). However, it has been noted that there does not appear to be a correlation between the results of the geophysical surveys and the observations and conclusions made by REECo during the borehole drilling and subsurface evaluation conducted in 1990 (see Appendix B for further discussion). This would suggest that the potential subsurface anomalies modeled in the geophysical studies may not be related to the presence of shallow perched groundwater as suggested and may even be the result of surface cultural features (e.g., site fencing) rather than natural features in the subsurface. The results of these surveys will likely be re-evaluated once additional subsurface 
drilling data become available in order to determine whether there is a correlation between observed subsurface conditions and modeled subsurface geophysical anomalies.

A 1994 sampling of the DPF by IT involved sampling of pond soil/sediment, berm material, and soil from the area of the 1991 spill from the pond. The preliminary evaluation included the analysis of surface soil samples taken from two locations within the pond (one location on the pond berm, one location in the 1991 spill area) and one background sample. Samples were also obtained from depths of $45.7,61.0$, and $91.4 \mathrm{~cm}(18,24$, and $36 \mathrm{in}$.) at one of the sample locations within the pond near the outflow pipe. The results of the sample analysis indicated contamination within the pond consisting of TPH, chlorobenzene (RCRA-list VOC), and potential man-made radionuclides (cesium-137 [Cs-137], thallium-28 [Tl-208], cobalt-60 [Co-60], and americium-24 [Am-241]) as well as elevated gross beta levels. Tl-208 was detected in samples from inside and outside of the pond including the area sampled for background comparison, indicating that the Tl-208 may be a background contaminant.

In March 1996, IT conducted a preliminary evaluation of the DPF consisting of a field surface radiologic survey and a systematic random surface soil sampling. Most of the sample analytical results from this preliminary evaluation are available for this plan (see Appendix B) and have been important in determining the distribution of contaminants at the surface and the contaminants of concern (COC) present in the soil. Based on the initial analytical results for the samples, additional radioisotopic analyses are being conducted to determine the cause of elevated gross alpha and beta content in some samples. The results of the surface radiologic survey suggested a bimodal trend for radioactive contaminants with the greatest activity or concentration near the pond inlet and a second elevated area on the other side of the pond, directly across from the inlet. No elevated readings were observed outside of the pond berm. Surface soil samples tend to confirm the distribution of contaminants in a similar pattern to the surface survey results with little or no contamination observed outside of the pond berms. The observed contaminants consisted of TPH, polychlorinated biphenyl (i.e., Aroclor 1254), Co-60, Cs-137, Am-241, gross alpha, and gross beta. In addition, Tl-208, which can be man-made, was observed in a distribution, suggesting that its presence is not related to the activities associated with the DPF (i.e., distributed with greater activities outsicle of the DPF than inside the DPF). The final planning and implementation of subsequent characterization phases have been based on the results of the preliminary characterization activities. While additional information and evaluation results are presented in Appendix B, the complete data evaluation results will be presented in the final characterization report for the site. 


\subsection{Objectives}

\subsection{Conceptual Model}

The conceptual model for the site takes into account the known or assumed source of the problem, the potential migration pathways, potential receptors, constituents of concern, and the required or anticipated drivers for the characterization and closure. The conceptual model for the DPF was developed from archival investigations of the site, process knowledge (DOE, 1988b; REECo, 1991a), and the results of preliminary field investigations discussed earlier. The model was developed to be used as a basis for the site characterization plan and is described as follows:

\section{Conceptual Model for the Area 6 Decontamination Pond Facility}

\section{KNOWN CONTAMINANT SOURCE(S)}

- Hazardous, radioactive, and petroleum hydrocarbon wastes have been discharged/disposed above regulated levels in the Area 6 Decontamination Pond Facility from nearby steam-cleaning decontamination and laundry decontamination activities.

- The Area 6 DPF is an unlined evaporation pond constructed on native soils of generally low porosity and permeability.

\section{HYPOTHESIZED MIGRATION PATHWAYS}

- Evaporation of most liquids and volatile contaminants from the liquids discharged to the ponds

- Vertical infiltration of remaining liquids and volatile and nonvolatile contaminants into underlying low-permeability soil and minor lateral infiltration into surrounding berm material and low-permeability soil

- Deposition of contaminants in the surrounding soil to a vertical depth of $1.2 \pm$ $0.6 \mathrm{~m} \mathrm{(} 4 \pm 2 \mathrm{ft}$ ) below ground surface (bgs) and a lateral infiltration of less than $1.2 \pm 0.6 \mathrm{~m}(4 \pm 2 \mathrm{ft})$ inward from the interior berm faces

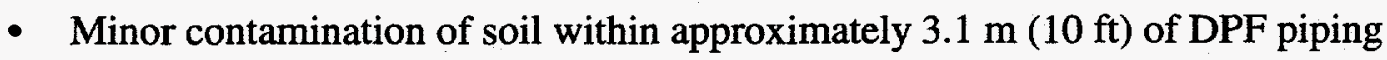
and soil/oil/water (SOW) separators 
- Shallow perched groundwater is not present below the site at less than $30.5 \mathrm{~m}$ (100 ft) below ground surface (bgs) and/or is not impacted by the contaminants of concern originating from the $\mathrm{DPF}$.

- See Figures 3-1 and 3-2.

\section{POTENTIAL RECEPTORS}

- Nearby NTS personnel are considered to have a minimal exposure and associated risk primarily resulting from the potential for wind dispersion of contaminants in and around the edges of the DIPF.

- Plants and animals (i.e., birds, small mammals, and reptiles) are considered to have a minimal exposure and associated risk.

- Future land use in close proximity to the site could be negatively impacted by the presence of contamination remaining at the site. The actual level of impact on future land use may depend, in part, on the method used to close the site and the results of the Environmental Impact Statement (EIS) (i.e., the site use option selected for the NTS) that is currently being prepared for the NTS.

\section{CONTAMINANTS OF CONCERN}

The COCs for the DPF are separated into various groups based on defined study areas which are depicted in Figures 3-1 and 3-2. The COCs based on study areas are as follows:

- Study Area 1 contaminated sludge, sediment, and/or soil on the pond bottom, and contaminated soil below and around the pond surface - RCRA-regulated VOCs, SVOCs, and/or metals present (i.e., above detection limits) but below Nevada Division of Environmental Protection action levels (NDEP, 1992) and Land Disposal Restriction (LDR) levels; radionuclides above the NTS Performance Objective for Certification (POC) of Nonradioactive Hazardous Waste (BN, 1996) action levels; and total petroleum hydrocarbons (TPH) above the NDEP action level of 100 milligrams/kilogram (mg/kg)

- Study Area 2 - Uncontaminated soil below and around the pond

\section{REQUIRED AND/OR ANTICIPATED CONTROLS ON THE} CHARACTERIZATION

The following are aspects of the conceptual model that effect or control how the site will be characterized based generally on logistical, economic, and regulatory constraints: 


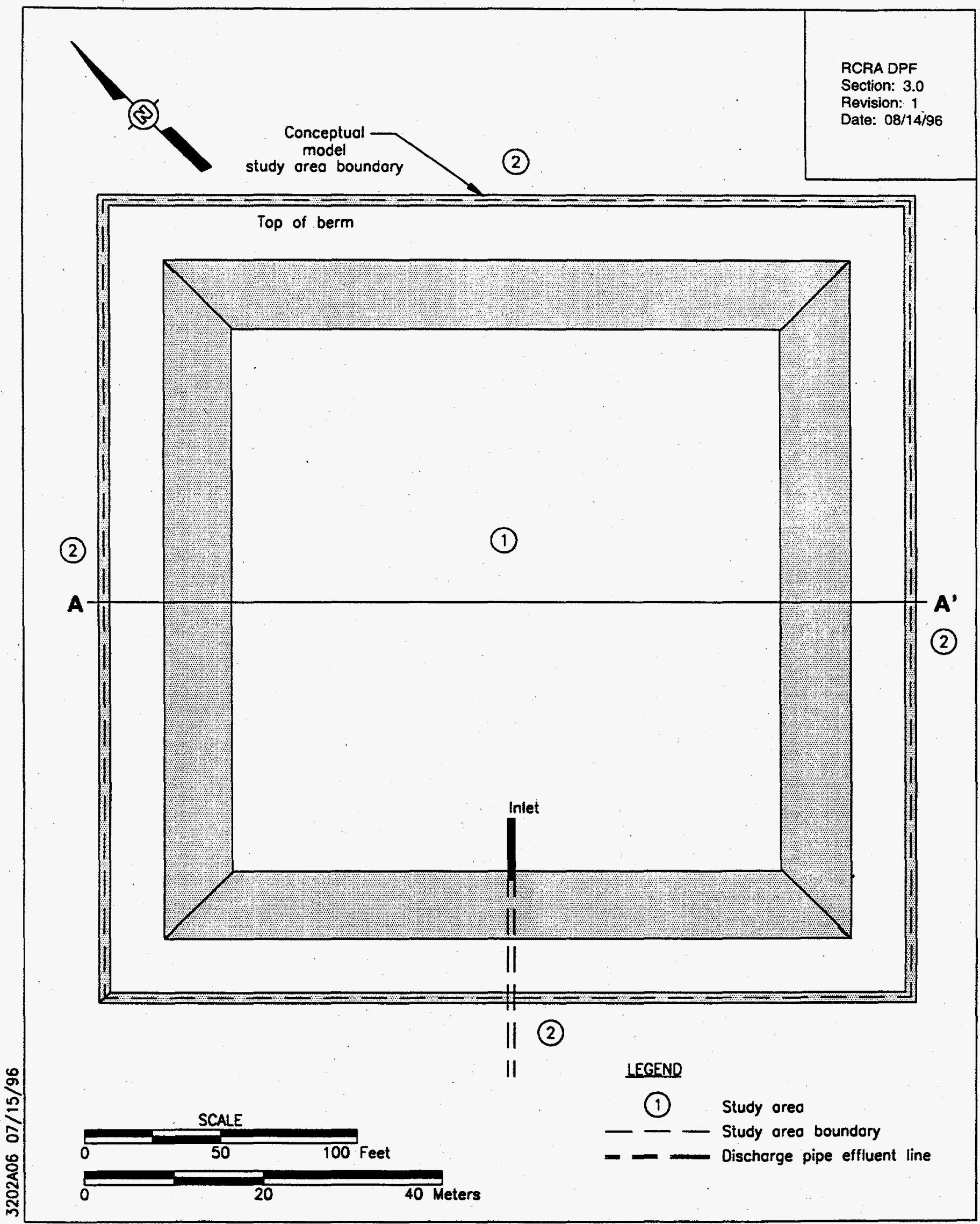

Figure 3-1

Map View of the Conceptual Model for the Area 6 Decontamination Pond Facility 


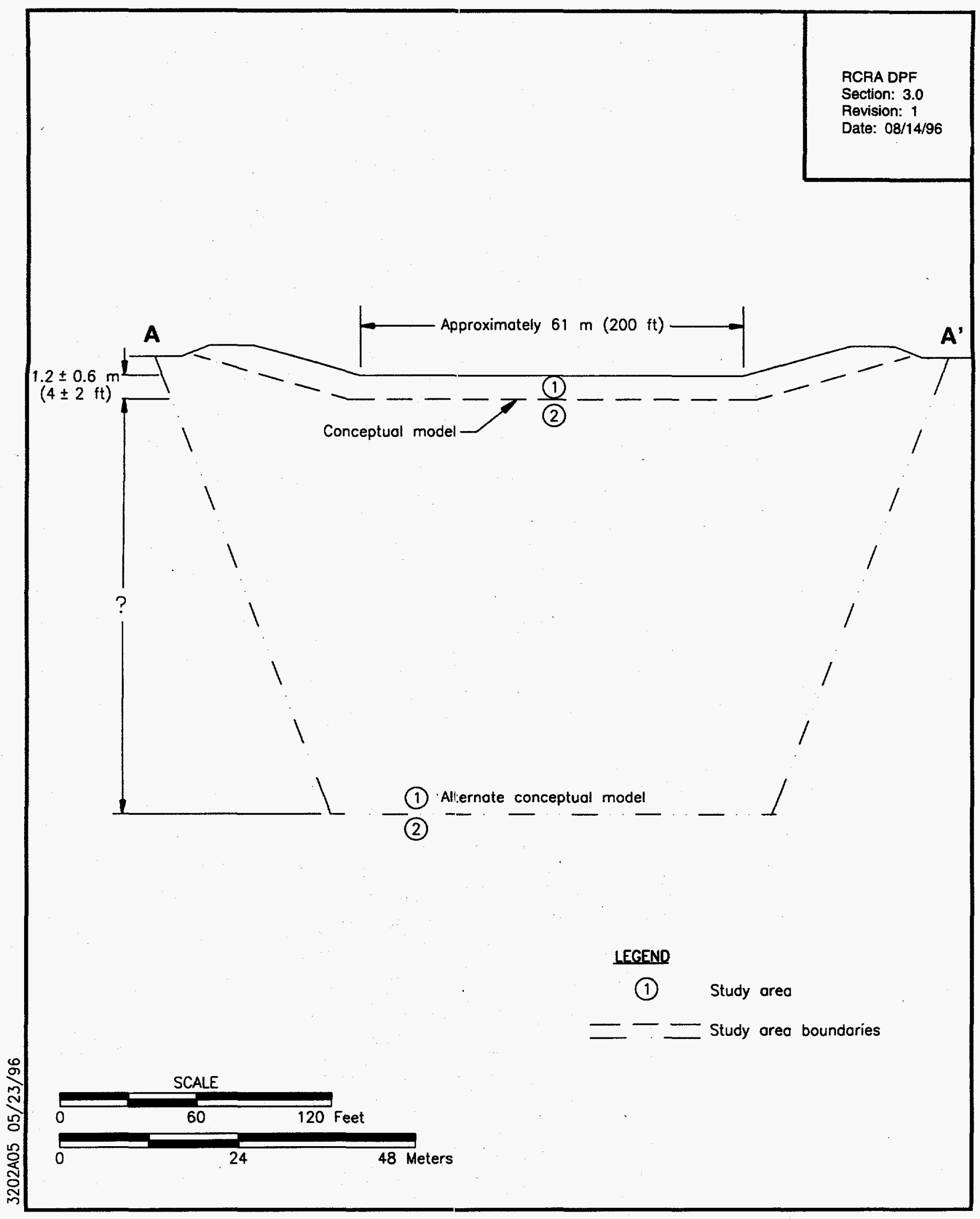

Figure 3-2

Cross-sectional View of the Conceptual Model for the Area 6 Decontamination Pond Facility 
- Contaminant volumes to be removed with respect to the following activities:

- The amount of investigation-derived waste generated as a result of characterization activities

- The logistics and cost for managing IDW

- The most likely closure strategies for the site (i.e., closure in place or removal of contaminated media)

- Contaminant/waste types

- A significant amount of mixed, hazardous, and radioactive waste is expected at the site.

- The RCRA-regulated contamination is expected to be below NDEP action levels and LDRs.

- The majority of the contamination is expected to be low-level waste (LLW) or mixed waste with RCRA-regulated constituents below NDEP action levels.

- Some areas of the site are expected to be uncontaminated.

- Regulatory requirements with respect to the following activities:

- Much of the contamination is expected to be below the NDEP action levels (NDEP, 1992) for requiring remediation.

- Much of the IDW generated during the characterization activities is expected to be mixed waste below the LDRs which can be managed on site by staging during the characterization activities and disposing at NTS facilities after completion of the characterization activities.

- Mixed waste above the LDR levels, if generated, shall be staged and containerized on site and moved to the Area 5 Radioactive Waste Management Site Transuranic Waste Storage Pad (TRU Pad)

- RCRA-regulated, non-radioactive IDW, if generated, shall be staged and containerized on site and shipped off site for disposal

- Site closure is regulated under Title 40 CFR 265.228, Nevada Administrative Code 459.9973, and the NTS RCRA permit NEV HW009 
The sampling objectives will confirm, evaluate, and potentially modify or refute the conceptual model presented and have been used to develop a sampling methodology to ensure that datacollection activities provide data that are meaningful, valid, and defensible and which lead to development of a closure strategy. This approach identifies areas of concern (i.e., areas which violate the conceptual model) early in the characterization and then targets those areas for additional investigation, as needed.

\subsection{Data Quality Objectives (DQOs)}

The specific results of the DQO process are summarized and presented as Section 3.1 and Section 4.0 of this plan and/or are maintained in project files. The approach to site characterization at the DPF is an iterative process. As part of the Quality Assurance (QA) and Quality Control (QC) program for the project, a seven-stage approach, as described in Guidance for the Data Quality Objectives Process (EP'A, 1993a, 1993b, 1994), has been employed to ensure that the environmental data gathered for site characterization are adequate to support further characterization, remediation, and/or the development of a closure strategy for the DPF. The DQO process allows conceptual models and resulting project decisions to be refined as additional information or data needs are discovered or generated during the implementation of the site characterization.

The DQO process outlined by EPA (1993a and 1994) consists of seven steps that have been applied to design the initial sampling plan and will be re-evaluated as more information becomes available during the site investigation. These steps are:

- Problem Statement - stating the problem to be resolved and developing a conceptual model for the site (Section 3.1)

- Identification of Decisions - the principle study question(s) that must be answered by the characterization and the decision process

- Decision Inputs - identification of inputs to the decision (i.e., data needs)

- Study Boundaries - definition of the characteristic, spatial, and temporal study boundaries

- Decision Rules - development of decision rules (i.e., logic statements)

- Decision Error Limits - development: of limits on decision errors (i.e., uncertainty constraints) 
- Optimize the Design for Obtaining Data - develop a sampling and analysis plan that satisfies the needs identified in Steps 1 through 6 (Section 4.0)

The DQOs for the characterization were also developed to adhere to the precision, accuracy, representativeness, comparability, and completeness (PARCC) parameters, as discussed in the RCRA Industrial Sites Quality Assurance Project Plan (QAPP) (DOE, 1994b).

\subsection{Technical Approach}

Based on the results of the DQO process, the technical approach to the completion of characterization activities at the DPF will involve the following steps:

- Surface and/or subsurface environmental samples will be collected and analyzed to determine concentrations of suspected COCs in the potentially affected environment. The field sampling and analytical programs have been designed to meet the DQOs for site characterization and are presented in the Sampling and Analysis Plan found in Section 4.0 of this plan.

- Analytical data will be used to determine if the conceptual model for the site is valid or if additional characterization is required to support an alternative model. The data will also be used to propose a plan to achieve closure of the site and to evaluate the regulatory status of waste generated during the field activities.

The field investigative program shall be conducted to allow for either the modification or termination of the characterization activities (when it is determined that sufficient data exists to support or refute the conceptual model). Based on the conceptual model, the characterization is planned for one phase of investigation to consist of subsurface soil sampling to an approximate depth of $4.9 \mathrm{~m}(16 \mathrm{ft})$ below ground surface within and around the DPF via drilling techniques.

However, if the conceptual model is proven to be incorrect (e.g., contamination is deeper or more wide spread than projected) during the planned activities, two contingencies have been developed in order to adjust the scope of the characterization consistent with alternate conceptual models (see Figure 3-2). The alternate model(s) assume that pond infiltration was more significant, and contaminants have migrated to a deeper extent and/or greater lateral extent than indicated in the primary conceptual model. The contingencies include:

- If the contamination is deeper than anticipated, the contingency is having the ability to

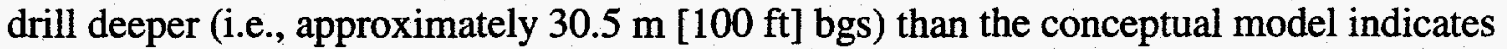
if regulated contamination is present (Alternate Model 1). 
- If the contamination covers a larger area or is more complexly distributed, the contingency is having the ability to include more extensive subsurface soil sampling outside and potentially inside of the DPF via drilling techniques (Alternate Model 2).

Contingent investigations may be carried out as part of subsequent characterization phases and will be based on the results of the Phase I investigation. Detailed discussions of the plans for sampling and analysis of the site are contained in Section 4.0 of this plan. 


\subsection{Sampling and Analysis Plan}

Data will be collected during the field investigation to confirm or refute the conceptual model for the site and, thus, assess the migration of potential COCs and to determine if COCs are present in concentrations exceeding levels protective of human health and the environment (i.e., regulatory action levels). Samples will also be collected in order to obtain site-specific geotechnical information applicable to the evaluation of remediation and/or closure options. Sampling will be conducted to allow for definition of migration pathways consistent with the DQOs and to provide adequate data to support or develop a closure strategy. The characterization activities (i.e., sampling, decontamination, etc.) will be conducted in accordance with approved sampling instructions and operating procedures and the RCRA Industrial Sites QAPP (DOE, 1994b). For the purpose of the characterization, the site boundaries will be configured to include the DPF and

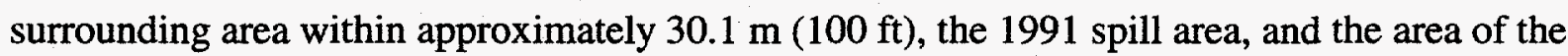
piping release.

This sampling and analysis plan will be executed as described in the following sections. Unexpected site conditions may require modification of the methods described in this section as well as the conceptual model for the site and/or the DQOs for the characterization. The following sections detail the technical approach and activities that will be conducted for the characterization.

\subsection{Site Preparation Activities}

A topographic survey was conducted at the DPF in order to make comparisons with as-built drawings for the facility and potentially estimate the amount of sediment that has been deposited in the pond. At the same time, a sampling grid was established across the pond and the associated spill area. The grid forms the basis for systematic random sampling patterns that have been and may be conducted at the site.

An access way into the pond will be constructed to facilitate entrance to the pond by drilling and support vehicles. Clean soil and/or gravel will be used to construct a ramp on the interior and exterior of the pond up to the height of the pond berm. No excavated material will be removed from the unit during the construction of the access way. Figure 4-1 depicts the approximate configuration of the access way. 


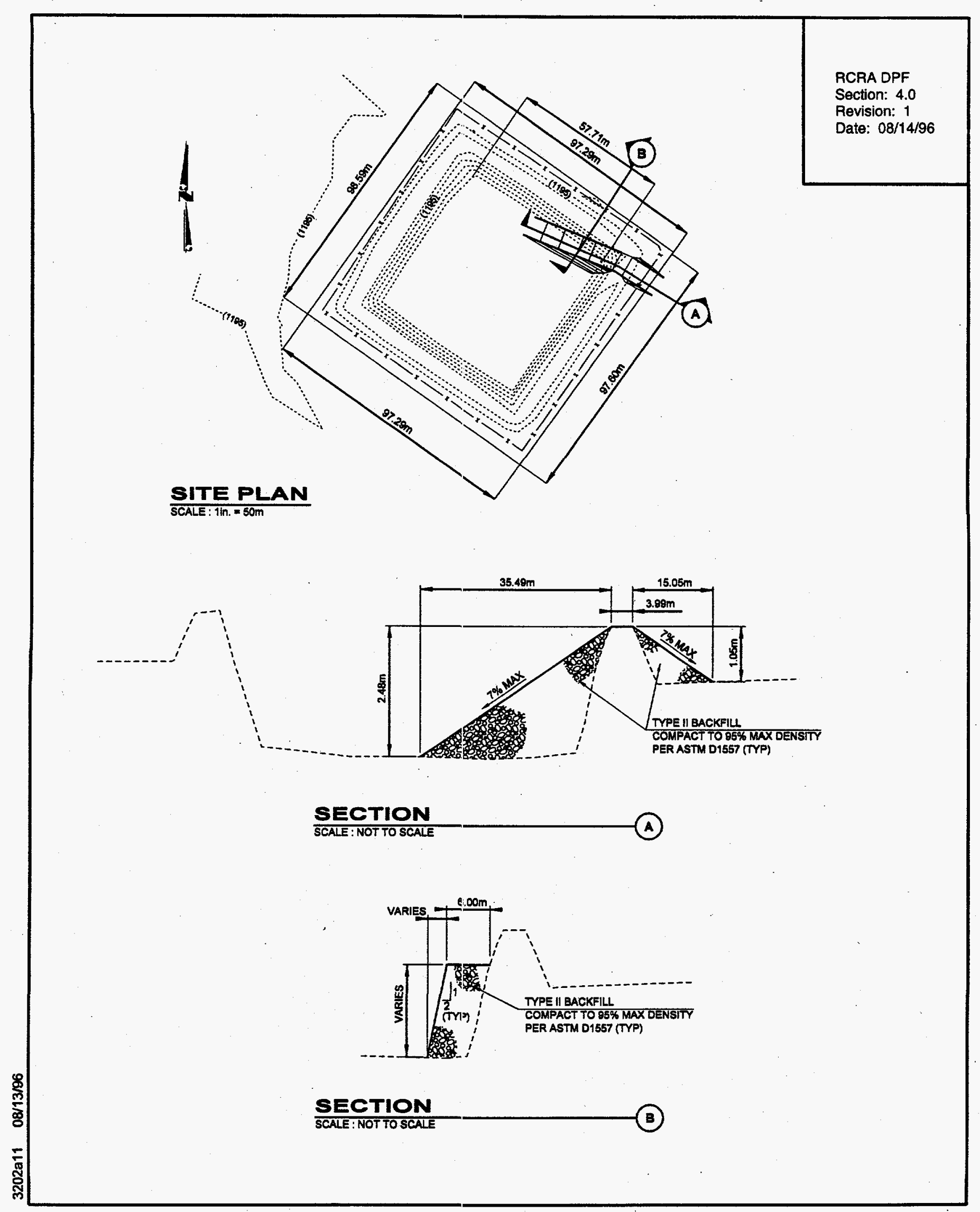

Figure 4-1

Conceptual Morjel of Access Ramp for

Area 6 Decontamination Pond Facility 


\subsection{Drilling Activities}

Drilling activities will be conducted using a hollow-stem auger drill rig capable of boring to depths of approximately $30 \mathrm{~m}$ (100 ft). However, it is anticipated that drilling will only be

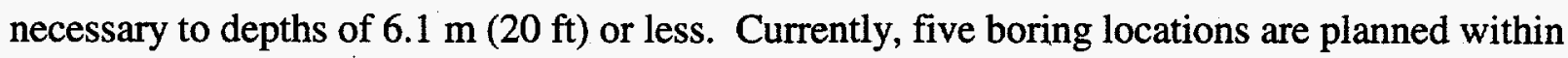
the pond, and four boring locations are planned outside of the pond. Additional borings may be drilled based on field indications of contaminant migration trends. The initial boring locations are based on the grid that has been surveyed on the site (see Figure 4-2) and on the results of the March 1996 preliminary sampling (see Appendix B). The results of borings within the pond (as determined through field screening and observation and/or quick turn-around sample analyses) are likely to affect the location of borings conducted outside of the pond. Industrystandard methods for determining the locations for step-out borings will be used if lateral migration of subsurface contaminants is suspected or observed. Step-out borings will either be placed in configurations that are based on known contaminant trends or in geometric configurations (i.e., a triangular pattern originating from the center of the pond or contamination) if contaminant migration trends have not been established.

\subsection{Sampling Activities}

Sampling activities will focus on further characterizing COCs, evaluating COC concentrations below the ground surface, and defining contaminant extent to confirm or refute the conceptual model for the site. The sampling activities will also be used to determine waste types for appropriate waste minimization options and management requirements. All samples will be field-surveyed for radiation hazards. All samples will also be field-screened for VOCs using a photoionization detector (PID) or flame ionization detector (FID) with the head-space technique and may also be screened for radionuclides using appropriate portable detection systems. Selected samples will be sent to an approved off-site laboratory to be analyzed for more complete characterization. The analytical methods to be used are discussed in Section 4.4 of this plan.

The boundaries between the various study areas defined in the conceptual model will be determined initially through visual indications of impact followed by on-site screening (as discussed above) of samples. If off-site analysis of samples indicate the presence of contamination not attributed to the current study area, then the conceptual model may be changed appropriately to account for such differences that might affect later characterization or site closure activities. 


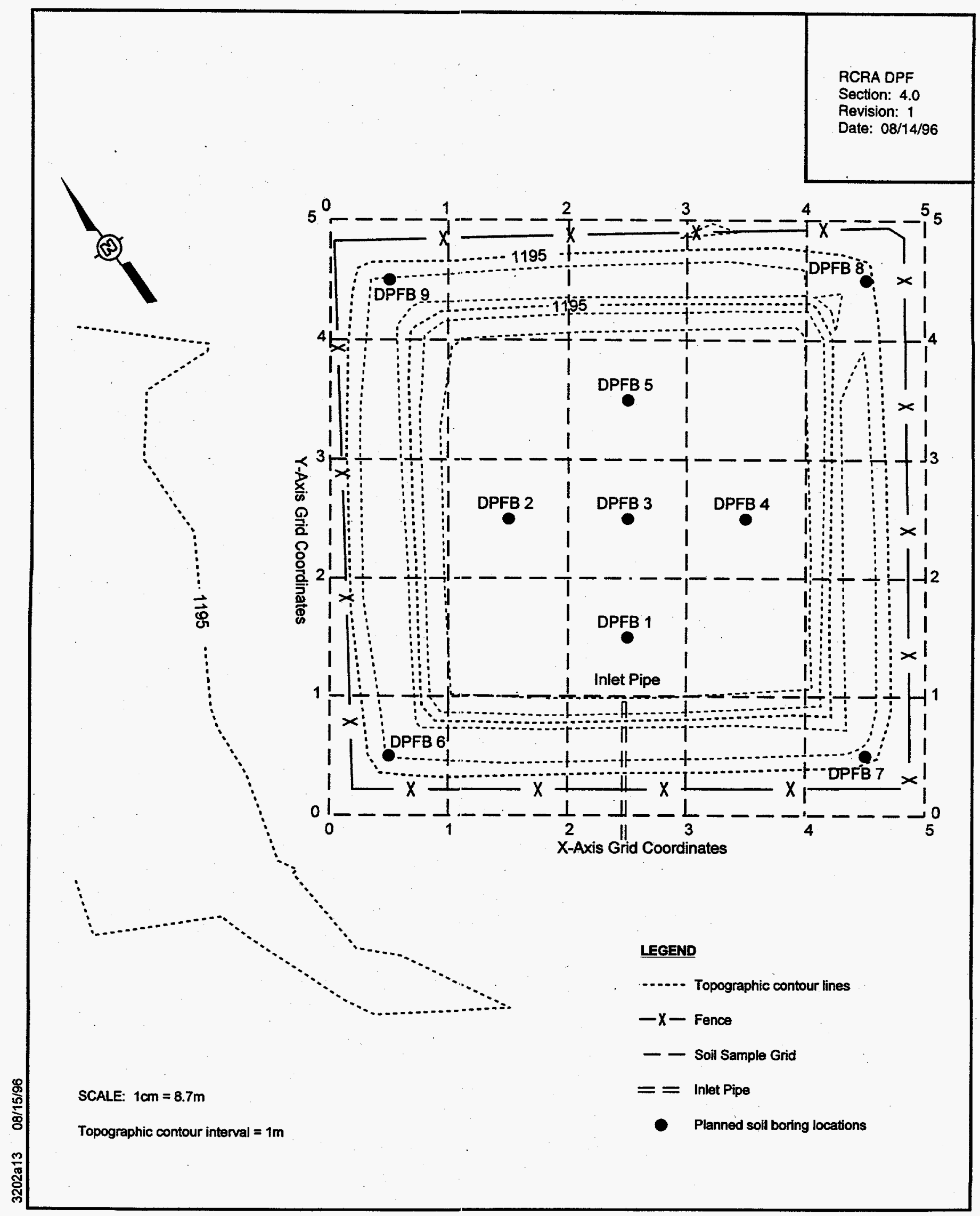

Figure 4-2

Planned Soil Boring Locations Area 6 Decontamination Pond Facility 
Samples will be collected from soil borings using a split-spoon sampler or core barrel at approximate $0.8-\mathrm{m}(2.5-\mathrm{ft})$ intervals beginning at approximately $0.31 \mathrm{~m}(1 \mathrm{ft})$ and proceeding to a depth of approximately 1.8 to $4.9 \mathrm{~m}$ ( 6 to $16 \mathrm{ft}$ based on the current conceptual model). Sampling in this manner amounts to approximate continuous sampling from 0 to $4.9 \mathrm{~m}$ ( 0 to

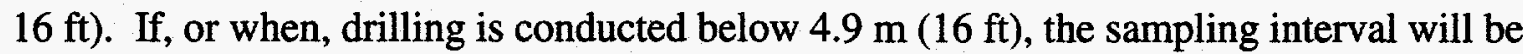
increased to $1.5 \mathrm{~m}(5 \mathrm{ft})$. Before terminating a boring, at least two unimpacted samples (as identified through on-site screening and analysis results) will be collected from approximately 1.5 and $3.1 \mathrm{~m}$ ( 5 and $10 \mathrm{ft}$ ) below any encountered contaminant zones. When possible, at least three samples for laboratory analysis will be collected from encountered contaminant zones (i.e., one sample each from the top and bottom and the area of highest suspected contamination within the zone). In other words, if the encountered contamination is less than two sampling intervals thick, then less than three samples will be obtained for laboratory analysis.

All collected samples will be screened on site using various field screening techniques (e.g., radionuclide/radiation detectors, flame-ionization detector, photoionization detector, calorimetric screening, etc.). It is anticipated that approximately 20 samples may be obtained from within the DPF based on the current conceptual model and a drilling pattern based strictly on the surveyed grid system (i.e., five planned drilling locations within the DPF). An additional 16 samples could result from drilling at four planned drilling locations around the pond and 12 samples from three locations in the vicinity of the piping release. Samples to be analyzed by the off-site laboratory will be selected based on the results of field screening and planned sampling intervals. The actual number of samples analyzed will depend on decisions made in the field. Additional (or fewer) characterization samples may be sent for off-site analysis based on field screening results, field indications of potential changes in contaminant characteristics (i.e., contaminant type, concentration, mobility, etc.), and the results of sample analysis when they become available.

\subsection{Sample Analysis}

Table 4-1 lists the analytical methods that will be applied to soil samples. The analytical methods have been chosen based on the results of the preliminary investigations, process knowledge of the past use of the DPF, and any additional regulatory and DOE guidance or requirements. Based on the results of preliminary sampling and review of process knowledge information, it is expected that the contamination associated with the DPF is hydrocarbon, potentially RCRA-regulated VOCs, and/or radionuclides. Radioactive or mixed contamination are expected and will be investigated during both the site and waste characterization sampling. 


\section{Table 4-1}

\section{Characterization Analytical Methods}

\begin{tabular}{|c|c|c|c|c|}
\hline Analytical Parameter & $\mathrm{sc}^{\mathrm{a}}$ & $w c^{b}$ & $\mathrm{FS}^{\mathrm{C}}$ & Analytical Methods ${ }^{d}$ \\
\hline \multicolumn{5}{|c|}{ Chemical and Radiological Analyses } \\
\hline Total petroleum hydrocarbons - gasoline & $\mathrm{x}$ & $x$ & $x$ & EPA 8015 Modified \\
\hline Total volatile organic compounds & $x$ & $\mathrm{x}$ & $\mathrm{x}$ & EPA 8240 \\
\hline Total petroleum hydrocarbons - diesel and oil & $x$ & $\mathrm{x}$ & $x$ & EPA 8015 Modified \\
\hline Total semi-volatile organic compounds & & $\mathrm{x}$ & $x$ & EPA 8270 \\
\hline Toxicity characteristic metals & & $\mathbf{X}$ & $x$ & EPA $1311 / 6010$ EPA $1311 / 7470$ \\
\hline Gamma scan & $\mathrm{x}$ & $\mathrm{x}$ & $x$ & HASL $300,4.5 .2 .3^{\dagger} /$ EPA 901.1 \\
\hline Gross alpha-beta & $x$ & $\mathrm{x}$ & $\mathbf{x}$ & SM $7110^{9} / E P A 900.0$ \\
\hline Plutonium-239/240 & $\mathrm{x}$ & $\mathrm{x}$ & $x$ & NAS-NS-3058 ${ }^{h}$ \\
\hline Strontium-89/90 & $x$ & $x$ & $x$ & Sr-7500i \\
\hline Tritium & & $x$ & $x$ & EERF H.01 \\
\hline Free liquids paint filter test & & $x$ & & EPA 9095 \\
\hline \multicolumn{5}{|c|}{ Hydrologic Analyses } \\
\hline Initial moisture content. & $x$ & & & ASTM $^{k}$ D 2216-92/D 4643-93 \\
\hline Dry bulk density & $x$ & & & ASTM D 2937-94/MOSA Chapter 13 \\
\hline Calculated porosity & $\mathrm{x}$ & & & MOSA Chapter 18 \\
\hline Saturated hydraulic conductivity & $x$ & & & ASTM D 2434-68(94) \\
\hline Unsaturated hydraulic conductivity & $x$ & & & SSSAJ $^{m}, 1980$ \\
\hline Particle size distribution & $x$ & & & ASTM D 422-63(90) \\
\hline Moisture retention characteristics & & & & $\begin{array}{c}\text { MOSA Chapter } 26 \\
\text { ASTM D 2325-68(94)/MOSA Chapter } 26 \\
\text { SSSAJ, 1984 } \\
\text { MOSA Chapter } 24 \\
\text { SSSAJ, } 1982 \\
\text { ASTM D } 3252 \\
\text { MOSA Chapter } 23\end{array}$ \\
\hline \multicolumn{5}{|c|}{ Geotechnical Analyses* } \\
\hline Shrink/swell & $x$ & & & ASTM D 4943-89 \\
\hline Specific gravity & $x$ & & & ASTM D 854-92 \\
\hline
\end{tabular}

Note: Analyses performed on groundwater, if encountered, will depend on the results of the soil sampling

"Some or all of the geotechnical analyses may be eliminated prior to the beginning of the field work

${ }_{b}$ Required site characterization analysis

Required waste characterization analysis

Required full suite analysis

SW-846 (EPA, 1986) unless otherwise noted

One container per analysis or group of analyses

f Environmental Measurements Laboratory Procedure Manuai', HASL-300 (DOE, 1992b)

${ }_{9}^{9}$ Standard Methods for the Evaluation of Water and Waste Water (APHA, 1992)

hational Academy of Science, Nuclear Series (Coleman, 1965)

Eastern Environmental Radiation Facility (EPA, 1987)

Alpha Inc., 1960

${ }_{1}^{A}$ American Society for Testing and Materials

Methods of Soil Analysis (American Society of Agronomy, 1986)

Soil Science Society of America Joumal 
Sample collection and analysis for waste management purposes are discussed in Sections 5.3 and 5.4 of this plan. In addition to the chemical and radiological analyses to be conducted for characterization and waste management purposes, the bottom sample from each of the five planned borings within the DPF will be analyzed for an increased confirmation suite ("full suite") of analytes that have been requested by the Nevada Division of Environmental Protection. This suite is noted on Table 4-1.

Four samples for physical parameter analysis (see Figure 4-2) will be collected from the bottom of four of the boreholes below the field-detected contamination in order to evaluate the physical characteristics of the underlying soil with respect to how these characteristics might affect future remediation or closure options. 


\subsection{Waste Management Plan}

The requirements for managing of the wastes derived from the characterization will be determined based on regulatory requirements, field screening, and the results of off-site laboratory analysis of site characterization samples. Administrative controls (i.e., decontamination procedures and characterization strategies) will minimize the hazardous and/or mixed waste generated during site investigation activities. Hazardous, low-level radioactive, and/or mixed waste will be managed and disposed of in accordance with the Nevada Test Site Defense Waste Acceptance Criteria, Certification, and Transfer Requirements (NVO-325) (DOE, 1992b), DOE Orders, and U.S. Department of Transportation (DOT) and RCRA regulations. Decontamination activities will be performed in accordance with approved procedures as specified in the project field sampling instructions and will be designated according to the COCs present at the site. Requirements for the waste analysis will be presented in a separate plan that will address the specific requirements of NVO-325.

\subsection{Waste Minimization}

The characterization activities have been designed to minimize the amount of IDW produced through the segregation of different waste streams and the production of as little waste as possible. Initial site preparation activities (i.e., excavation of access ways and/or ramps) have been planned to remove no soil from the unit.

\subsection{Potential Waste Streams}

Based on preliminary sampling results and process knowledge, LLW and/or mixed wastes are anticipated. It is also likely that hazardous wastes will be produced from the DPF although they are not expected to exceed the LDR levels for listed hazardous wastes.

Wastes generated during the characterization of the DPF may include, but are not limited to, the following:

- Decontamination rinsate

- Contaminated sample management equipment (e.g., plastic, paper, aluminum foil, and sample containers)

- Personal protective equipment (PPE) 
- Samples returned from the laboratory

- Contaminated and uncontaminated soil (e.g., cuttings generated from drilling operations)

Samples may be returned from the laboratory for disposal by the generator if the samples are found to exceed established radioactive contaminant limits above which the laboratory can not dispose of the sample material. These limits affect only radioactive and/or mixed waste samples and are expected to result in the return of some samples from the DPF characterization activities. Any returned mixed waste samples that exceed the LDR levels will be transferred to the Area 5 TRU Pad pending determination of treatment and/or dispositioning requirements. The samples will be properly stored pending disposal according to the requirements of NVO-325.

\subsection{Waste Determination}

The status of IDW (i.e., TPH, RCRA-hazardous, LLW, and/or mixed waste) will be determined through the application of statistical analyses of sample data as described in Chapter 9 of SW-846 (EPA, 1986) for determining the RCRA status of waste, and the requirements of NVO-325 and the Nevada Test Site Performance Objective for Certification of Nonradioactive Hazardous Waste (BN, 1996) for determinirg the radioactive status of the waste. These issues will be discussed in greater detail in the NVD-325 waste management plan to be prepared for the site.

\subsection{Waste Management}

Plate 1 presents a waste management decision process flow chart for characterization activities. The object of the flow chart is to guide the management of IDW. In order to answer the questions in this flow chart, the appropriate waste data must be obtained with respect to the contaminants encountered during sample analysis. From the data generated as a result of contaminant characterization, it should be possible to assign the appropriate waste type (i.e., hazardous, mixed, LLW, TPH, or unreggulated) to the IDW.

As indicated, if mixed waste is produced, the appropriate waste data must also be obtained or developed in accordance with the TRU Pad waste acceptance criteria. The number of samples necessary to satisfy the various mixed waste management requirements (i.e., RCRA, NVO-325 [DOE, 1992b]) will depend on the number of containers of IDW produced, the volume of IDW produced, and/or the variability in the analytical values for the IDW produced. 
Solid materials other than soil wastes are waste only by virtue of contact with contaminated media. Therefore, sampling and analysis of the investigation-derived waste (other than soil cuttings), separate from site characterization analyses, will not be required. However, in order to address contractor-specific waste management requirements, a composite sample of the decontamination rinsates produced during the characterization activities shall be collected and analyzed for the waste management parameters discussed in Section 5.4. Administrative controls will be used to ensure that no additional contaminants are added to the waste.

For administrative purposes, the waste will be managed as at least four waste streams: nonimpacted soil, impacted soil/sludge, solid (i.e., non-soil) waste, and decontamination rinsate. Each waste stream will be segregated, and additional segregation may occur within each waste stream. For example, the soil waste produced from each separate study area will be segregated. Wastes will be managed on site within the defined site boundaries until analytical results are received to determine the disposition of the waste. Liquid low-level or mixed wastes, if present, will be absorbed or solidified prior to disposal or storage. Access to wastes temporarily staged at the project site will be controlled through placing the waste packages or waste soil piles within an access-controlled accumulation area. All waste containers or soil piles shall be covered and/or locked (i.e., drums) and appropriately labeled. Waste containers shall be inspected weekly while awaiting laboratory results to ensure that the waste containers are not leaking or damaged.

IDW streams will be placed in waste containers such as DOT-approved drums. The contents of each container will be recorded, and each container will be appropriately marked and labeled in accordance with RCRA and DOE requirements.

Soil waste will be segregated according to the conceptual model study area and/or soil boring from which it is removed and containerized (see Sections 3.1 and C.1.4). The anticipated volume of waste-contaminated soil to be generated during the characterization is approximately 4.3 cubic meters (5.6 cubic yards). In the event that mixed waste exceeding LDR levels is generated, it will be stored at the TRU Pad in appropriate containers after having met the appropriate waste acceptance criteria. Low-level waste or mixed waste that does not exceed LDR levels, if generated, will be disposed of at the NTS under the NVO-325 Requirements (DOE, 1992b). Hazardous, nonradioactive waste will be shipped off site to a permitted treatment, storage, disposal, or recycling facility. 


\subsection{Reporting}

Upon completion of the field activities and receipt of the sample analytical and data validation results (as applicable), a report of findings will be produced. The report will, at a minimum, include the following:

- Drawings of the site, including appropriate site boundaries, sampling locations, estimated boundaries of contamination, and other relevant features

- Brief discussions of the characterization methods used, including soil sampling methods, materials, and logs

- Information about the presence and concentrations of constituents of concern

- Tables summarizing laboratory analytical results and field screening data, where appropriate

- A discussion about the adequacy of the characterization of the site

- A discussion about the quality control data obtained for the characterization

- Recommendations for further assessment, remediation, or closure of the site 


\subsection{References}

Adams, S. (IT Corporation). 1996. Memorandum: Concentrations of Gross Alpha and Beta Emitters in Background Soil in the Vicinity of the NTS. Las Vegas, NV. 30 May.

Alpha Inc. 1960. Standard Methods for the Examination of Water and Waste Water, Sr-7500, 11 th Edition. New York, NY.

APHA, see American Public Health Association.

American Public Health Association. 1992. Gross Alpha and Gross Beta Radioactivity, Standard Methods for the Examination of Water and Waste Water, 18th Edition.

Washington, DC.

ASA, see American Society of Agronomy.

American Society of Agronomy. 1986. Methods of Soil Analysis, Part 1. A. Klute, ed. Madison, WI.

BN, see Bechtel Nevada.

Bechtel Nevada. 1996. Nevada Test Site Performance Objective for Certification of Nonradioactive Hazardous Waste. Las Vegas, NV.

Bicker, A.E. 1986. Letter Report to P. K. Fitzsimmons, Acting Director, U.S. DOE Nevada Operations Office, "NTS Mixed-Waste Assessment Summary." Las Vegas, NV.

Coleman, G.H. 1965. The Radiochemistry of Plutonium. NAS-NS3058. National Academy of Science.

Colton, R.B. 1965. Fissures in Playas, Nevada Test Site and Vicinity, Technical Letter NTS-137. Washington, DC: U.S. Geological Survey.

DRI, see Desert Research Institute.

Desert Research Institute. 1988. CERCLA Preliminary Assessment of DOE's Nevada Operations Office Nuclear Weapons Testing Areas, Vol. 1. Las Vegas, NV: DRI Water Resources Center.

DOE, see U.S. Department of Energy:

Doty, G. C. and F. E. Rush. 1985. Inflow to a Crack in Playa Deposits of Yucca Lake, Nevada Test Site, Nye County, Nevada, Water Resources Investigation Report 84-4296.

Washington, DC: U.S. Geological Survey. 
ES, see Engineering Science.

Engineering-Science. 1990. Resistivity Investigation at Area 6 Decontamination Pond, N.T.S. Pasadena, CA.

EPA, see U.S. Environmental Protection Agency.

Fernald, A.T. 1979. "Map of the Tuff Aquitard (Lower Tuff Units) in Yucca Flat, Nevada Test Site," USGS-474-262. Washington, DC: U.S. Geological Survey.

IT, see IT Corporation.

IT Corporation. 1992. Personal Communication, "Notes - Nevada Test Site Tour of RCRA Closure Sites," 17 June.

IT Corporation. 1995. Area 6 North Steam Cleaning Effluent Pond Preliminary Investigation. Las Vegas, NV.

IT Corporation. 1996. Geophysical Investigation Report for Area 6 Steam Cleaning Effluent Ponds and Decontamination Pond Facility and Area 23 Building 650 Leachfield, Nevada Test Site, Mercury, Nevada, Draft report. Knoxville, TN.

NDEP, see Nevada Division of Environmental Protection.

Nevada Division of Environmental Protection. 1992. Contaminated Soil and Groundwater. Remediation Policy. Carson City, NV.

REECo, see Reynolds Electrical \& Engineering Co., Inc.

Reynolds Electrical \& Engineering Co., Inc. 1986. Radiological Effluent and Onsite Area Monitoring Report for the Nevada Test Site (January 1985 through December 1985). Mercury, NV.

Reynolds Electrical \& Engineering.Co., Inc. 1988. Onsite Environmental Report for the Nevada Test Site (January 1987 through Decemiber 1987). Mercury, NV.

Reynolds Electrical \& Engineering Co., Inc. 1989. Onsite Environmental Report for the Nevada Test Site (January 1988 through Decemiber 1988). Mercury, NV.

Reynolds Electrical \& Engineering Co., Inc. 1990. Nevada Test Site Annual Site Environmental Report - 1989. Mercury, NV.

Reynolds Electrical \& Engineering Co., Inc. 1991a. Exploratory Drilling Investigation of the Proposed Site of the New Area 6 Decontamination Facility Evaporation Lagoons. Mercury, NV. 
Reynolds Electrical \& Engineering Co., Inc. 1991b. U.S. Department of Energy Nevada Operations Office Annual Site Environmental Report - 1990. Mercury, NV.

U.S. Department of Energy. 1986. A Guide for Environmental Radiological Surveillance at U.S. Department of Energy Installations. Washington, DC.

U.S. Department of Energy. 1988b. Environmental Survey Preliminary Report, Nevada Test Site, Mercury, Nevada. Washington, DC.

U.S. Department of Energy. 1988a. RCRA Part B Permit Application, Mixed Waste Management Facility, Nevada Test Site, Mercury, Nevada. Las Vegas, NV.

U.S. Department of Energy. 1989. Closure Plan, Area 6 Decontamination Facility Evaporation Pond, Nevada Test Site. Las Vegas, NV.

U.S. Department of Energy. 1990. Radiation Protection of the Public and the Environment, DOE Order 5400.5, Office of Environment, Safety, and Health. Washington, DC.

U.S. Department of Energy. 1991. Draft RCRA Closure Plan, Area 6 Decontamination Pond Facility, Nevada Test Site. Las Vegas, NV.

U.S. Department of Energy. 1992a. Environmental Measurements Laboratory Procedures Manual, HASL-300, 27th Edition, Volume 1. New York, NY.

U.S. Department of Energy. 1992b. Nevada Test Site Defense Waste Acceptance Criteria, Certification, and Transfer Requirements, NVO-325, Rev. 1. Las Vegas, NV.

U.S. Department of Energy. 1993. Draft Resource Conservation and Recovery Act Site Characterization Plan, Area 6 Decontamination Pond Facility, DOE/NV/10972-34. Las Vegas, NV.

U.S. Department of Energy. 1994a. Resource Conservation and Recovery Act Site Characterization Plan, Area 6 Decontamination Pond Facility, DOE/NV/10972-34. Las Vegas, NV.

U.S. Department of Energy. 1994b. Resource Conservation and Recovery Act Industrial Sites Quality Assurance Plan, Nevada Test Site, Nevada, Rev. 0. Las Vegas, NV.

U.S. Environmental Protection Agency. 1986. Test Methods for Evaluating Solid Waste, Physical/Chemical Methods, SW-846, 3rd edition with updates. Office of Solid Waste and Emergency Response, Washington, DC.

U.S. Environmental Protection Agency. 1993a. Data Quality Objectives for Superfund, Interim Final Guidance, EPA540-R-93-071. Washington, DC. 
U.S. Environmental Protection Agency. 1993b. Data Quality Objectives for Superfund, . Workbook, EPA540-R-93-078. Washington, DC.

U.S. Environmental Protection Agency. 1994. Guidance for the Data Quality Objectives Process, EPA QA/G-4. Washington, DC.

Winograd, I.J. and W. Thordarson. 1975. Hydrogeologic and Hydrochemical Framework, Southcentral Great Basin, Nevada-California, with Special Reference to the Nevada Test Site, U.S. Geological Survey Professional Paper 712-C. Washington, DC: U.S. Geological Survey.

Zohdy, A.R. and R.J. Bisdorf. 1979. Schlumberger Soundings and Geoelectric Cross-Sections in Yucca Lake, Nevada Test Site, Nevada, Open-File Report 79-220. Washington, DC: U.S. Geological Survey. 
RCRA DPF

Section: Appendix A

Revision: 1

Date: $08 / 14 / 96$

Appendix A

Environmental Setting 


\section{A.1.0 Environmental Setting}

\section{A.1.1 Topography}

Area 6 of the NTS is in Yucca Flat which is a typical north-south-oriented basin within the basinand-range physiographic province of the western United States. Bounded on the east and west by mountains, Yucca Flat is void of significant topography. The flat is approximately $31 \mathrm{~km}$ (19 $\mathrm{mi})$ long and $16 \mathrm{~km}$ (10 mi) wide, with elevation ranging from 900 to $1,400 \mathrm{~m}(3,000$ to $4,600 \mathrm{ft}$ ) above mean sea level (amsl) (DRI, 1988). Yucca Flat is a closed basin, with all runoff draining towards the basin axis and then south to the local base level, Yucca Lake (playa). The Area 6 Decontamination Pond Facility is located on the Yucca Lake bed near the western edge of the playa. The site topography consists of semi-flat surfaces with small drainages.

\section{A.1.2 Soils and Stratigraphy}

The shallow soils in Yucca Flat are typically formed on medial to distal alluvial and colluvial deposits. Soils and stratigraphy are important because of their physical and chemical properties which may inhibit the migration of chemicals of potential concern. Soil compositions are mostly sand, silt, and clay in a matrix supporting gravels to cobbles (up to 25.4 centimeters [10 inches]). The compositions of the pebbles and cobbles áre mostly limestone and volcanics. In the area of the DPF, these generally unconsolidated valley-fill deposits are mixed with evaporite deposits associated with the Yucca Lake playa. The Quaternary alluvial deposits at the site are up to $90 \mathrm{~m}$ $(300 \mathrm{ft})$ thick (DOE, 1988a).

The surface geology of the area suggests that the subsurface is likely to consist primarily of finegrained lake/playa deposits (e.g., silts, clays, and evaporite minerals) with minor interfingering coarse-grained alluvial sediments. Subsurface investigations conducted by REECo in 1991 (REECo, 1991a) in preparation for the possible construction of evaporation ponds to the south of the DPF confirm this stratigraphy down to approximately 15.2 to $22.9 \mathrm{~m}$ ( 50 to $75 \mathrm{ft}$ ) bgs.

\section{A.1.3 Surface Water}

The only perennial surface-water bodies on the NTS are several small springs and associated pools that occur on the flanks of ranges or the edges of topographic basins. The sources of spring recharge are perched saturated zones in highland ranges (Winograd and Thordarson, 1975). 
Yucca Flat is a playa on the NTS that receives and collects surface runoff during heavy precipitation. The runoff collects at Yucca l_ake, an ephemeral surface water-body at the southern end of Yucca Flat. Until it dissipates through evaporation or infiltration, surface water may be present in Yucca Lake for a few days or weeks. There has been one documented release from the Area 6 DPF to surface water in Yucca Lake (See Sections 2.2 and B.1.5).

Vertical cracks attributed to natural desiccation of fine-grained materials and/or tectonic activity have opened in the playa deposits of Yucca Lake (Doty and Rush, 1985; Colton, 1965). The rapid drainage of surface runoff into these cracks led to concern that water, along with any chemicals of potential concern or radionuclide constituents from NTS activities, was recharging the regional Paleozoic carbonate aquifer. The results of surface water and storm-water sample analyses for chemicals of potential concern and radionuclide constituents indicate that playa water entering such cracks does not present a human-health hazard (Doty and Rush, 1985).

Therefore, even if any chemicals of potential concern present in the DPF were to be released to standing water on Yucca Lake, it is highly unlikely that those chemicals would move with surface runoff to the regional aquifer through vertical cracks in the playa. Surface runoff away from the DPF is insignificant because the DPF was designed to retain precipitation and other liquids.

\section{A.1.4 Groundwater}

Within Yucca Flat, both the carbonate aquifers and the valley-fill aquifers supply water. Beneath the central part of Yucca Flat, the volcanic and Paleozoic rocks are saturated, and the lower part of the valley fill is also saturated. A vertical potentiometric gradient exists between aquifers in the valley fill, the volcanics, and the Paleozoic rocks. The shallower units have higher potentiometric heads than the deeper units. Regionally, groundwater migrates through the valley fill and volcanic units to the carbonate units. Groundwater flows southward from Yucca Flat to Frenchman Flat through the carbonate rocks with eventual discharge to springs in the Ash Meadows area of the Amargosa Desert. The discharge area is about $58 \mathrm{~km} \mathrm{(36} \mathrm{mi)} \mathrm{southwest} \mathrm{of}$ the Area 6 DPF.

The local water table in the area of the DPF is estimated to be approximately $460 \mathrm{~m}(1,500 \mathrm{ft})$ below the surface (DRI, 1988). Based on this depth, vertical and horizontal migration pathways through the unsaturated zone are likely to encounter a wide variety of lithology and structural mediums. 
Although several evaluations of Yucca Lake have been conducted, none of the evaluations have provided sufficient data to prove or disprove the presence of shallow purched groundwater in the area of the DPF. The presence of a perched water table was not noted in the results of Schlumberger soundings and geoelectric cross sections conducted at Yucca Lake in 1977. However, identification of shallow groundwater was not the purpose of the study, and the resolution (i.e., electrode spacing) may have been too coarse to detect perched water (Zohdy and Bisdorf, 1979). A resistivity investigation conducted for REECo at the Area 6 DPF in 1990 (ES, 1990) and a geophysical survey conducted by IT in 1994 (IT, 1996) did not confirm the presence or absence of a perched water table in the area. The two investigations do not appear to suggest the same configuration of potential subsurface anomalies and both of the investigations also appear to have been significantly influenced by the fence surrounding the DPF. It was noted that the auger bit was moist at a terminal drilling depth of $21 \mathrm{~m}(69 \mathrm{ft})$ in a borehole drilled by REECo approximately 61 to $91 \mathrm{~m}$ (200 to $300 \mathrm{ft}$ ) to the east of the DPF in 1990 (REECo, 1991a). However, none of the geophysical investigations suggested the presence of a subsurface anomaly in this area and a this approximate depth. Sections B.1.3, B.1.4, and B.1.7 discuss the 1990 geophysical and drilling evaluations and the 1994 geophysical evaluation in greater detail.

Two groundwater test wells (Well $\mathrm{C}$ and Well $\mathrm{C} 1$ ) are located approximately $1.6 \mathrm{~km}(1 \mathrm{mi})$ south of the DPF at the southeastern tip of Yucca Lake. Both wells penetrate the Paleozoic carbonate aquifer through a 242-m (794-ft) thick tuff aquitard (Fernald, 1979). At the DPF, the water table lies within the tuff aquitard at a depth of about $460 \mathrm{~m}(1,500 \mathrm{ft})$ below ground surface. A potential release of hazardous and/or radioactive waste constituents from the DPF would have to move about $460 \mathrm{~m}(1,500 \mathrm{ft})$ through unsaturated material to reach the water table. The possibility exists for accelerated vertical migration of chemicals of potential concern through local fractures. Pathways for migration of chemicals of potential concern from the DPF to groundwater sources will be assessed during site characterization. 
RCRA DPF

Section: Appendix B

Revision: 1

Date: 08/14/96

Appendix B

Results of Previous Evaluations 


\section{B.1.0 Results of Previous Evaluations}

Samples of both pond soil and water have been obtained from the DPF on at least five occasions in the past. Two geophysical evaluations have also been conducted. The following sections discuss the results of these evaluations.

\section{B.1.1 Pond Liquid Evaluations}

The liquid in the DPF was monitored for average tritium, gross beta, and Pu-239 levels as part of an NTS site-wide environmental monitoring program. Results for yearly monitoring in 1985 , 1987, 1988, 1989, and 1990 are presented in Table B-1.

Table B-1

Yearly Radiological Monitoring Result Averages

\begin{tabular}{||c||c|c|c||}
\hline Year & Tritium & Gross Beta & Pu-239 \\
\hline \hline $1985^{\mathrm{a}}$ & $3.6 \times 10^{-6} \mu \mathrm{Ci} / \mathrm{cc}$ & $3.6 \times 10^{-7} \mu \mathrm{Ci} / \mathrm{cc}$ & $<8.8 \times 10^{-11} \mu \mathrm{Ci} / \mathrm{cc}^{\mathrm{b}}$ \\
\hline $1987^{\mathrm{c}}$ & $3.9 \times 10^{-6} \mu \mathrm{Ci} / \mathrm{mL}$ & $8.6 \times 10^{-8} \mu \mathrm{Ci} / \mathrm{mL}$ & $<3.9 \times 10^{-10} \mu \mathrm{Ci} / \mathrm{mL}^{d}$ \\
\hline $1988^{\mathrm{e}}$ & $3.5 \times 10^{-6} \mu \mathrm{Ci} / \mathrm{mL}$ & $8.8 \times 10^{-8} \mu \mathrm{Ci} / \mathrm{mL}$ & $<1.7 \times 10^{-10} \mu \mathrm{Ci} / \mathrm{mL}$ \\
\hline $1989^{\prime}$ & $1.8 \times 10^{-6} \mu \mathrm{Ci} / \mathrm{mL}$ & $2.0 \times 10^{-7} \mu \mathrm{Ci} / \mathrm{mL}$ & $5.2 \times 10^{-12} \mu \mathrm{Ci} / \mathrm{mL}^{9}$ \\
\hline $1990^{\mathrm{h}}$ & $7.5 \times 10^{-7} \mu \mathrm{Ci} / \mathrm{mL}$ & $2.8 \times 10^{-7} \mu \mathrm{Ci} / \mathrm{mL}$ & $3.2 \times 10^{-11} \mu \mathrm{Ci} / \mathrm{mL}^{i}$ \\
\hline
\end{tabular}

a REECo, 1986

Microcuries per cubic centimeter

REECo, 1988

Microcuries per milliliter

${ }^{\text {REECO, }} 1989$

REECo, 1990

${ }_{\mathrm{Pu}}^{\mathrm{Pu}-239+240}$

hREECo, 1991b

Pu-239+240

\section{B.1.2 1986 Pond Mixed Waste Evaluation}

In June 1986, as part of the NTS Mixed Waste Assessment Summary (Bicker, 1986), a water sample was obtained from near the western-most shore of the DPF, $0.3 \mathrm{~m}(1 \mathrm{ft})$ from the inlet pipe. The sample was analyzed for the complete set of VOCs, SVOCs, and metals listed in Title 40 CFR 122, "National Pollutant Discharge Elimination System," and radioactive constituents. Analytical results are provided in Table B-2. 
Table B-2

Analytical Results for Water Samples, June $1986^{a}$

\begin{tabular}{|c|c|c|}
\hline Constituent & Concentration $^{b}$ & Regulatory Action Level $^{c}$ \\
\hline \multicolumn{3}{|l|}{ Volatile Organic Compounds } \\
\hline Acetone $^{d}$ & $0.130 \mathrm{mg} / \mathrm{L}^{\theta}$ & $4 \mathrm{mg} / \mathrm{L}^{f}$ \\
\hline Chlorobenzene $^{d}$ & $0.250 \mathrm{mg} / \mathrm{L}$ & $0.7 \mathrm{mg} / \mathrm{L}$ \\
\hline Methylene chloride $^{d}$ & $0.045 \mathrm{mg} / \mathrm{L}$ & $0.005 \mathrm{mg} / \mathrm{L}$ \\
\hline Xylenes (total) & $0.036 \mathrm{mg} / \mathrm{L}$ & $70 \mathrm{mg} / \mathrm{L}$ \\
\hline \multicolumn{3}{|c|}{ Semivolatile Organic Compounds } \\
\hline bis(2-ethylhexyl)phthalate & $100,000 \mathrm{mg} / \mathrm{L}$ & $0.003 \mathrm{mg} / \mathrm{L}$ \\
\hline \multicolumn{3}{|l|}{ RCRA' Metals } \\
\hline Barium & $0.5 \mathrm{mg} / \mathrm{L}$ & $1 \mathrm{mg} / \mathrm{L}^{\mathrm{h}}$ \\
\hline Chromium & $0.04 \mathrm{mg} / \mathrm{L}$ & $0.1 \mathrm{mg} / \mathrm{L}$ \\
\hline Lead & $0.10 \mathrm{mg} / \mathrm{L}$ & $0.3 \mathrm{mg} / \mathrm{L}$ \\
\hline \multicolumn{3}{|l|}{ Radionuclides } \\
\hline Gross Alpha & $<2.7 \times 10^{-11} \mathrm{pCi} / \mathrm{L}^{\mathrm{i}}$ & $15 \mathrm{pCi} / \mathrm{L}$ \\
\hline Gross Beta & $2.99 \times 10^{-10} \mathrm{pCi} / \mathrm{L}$ & $4 \mathrm{mrem} / \mathrm{yr}^{\mathrm{j}}$ \\
\hline Tritium & $6.35 \times 10^{-9} \mathrm{pCi} / \mathrm{L}$ & $20,000 \mathrm{pCi} / \mathrm{L}$ \\
\hline Plutonium-239 & $<1.7 \times 10^{-13} \mathrm{pCi} / \mathrm{L}$ & Not Available \\
\hline Strontium-90 & $<1.5 \times 10^{-12} \mathrm{pCi} / \mathrm{L}$ & $8 \mathrm{pCi} / \mathrm{L}$ \\
\hline
\end{tabular}

a Sources: Bicker, 1986; DOE, $1988 \mathrm{a}$

Only detectable levels are reported

Title 40, Code of Federal Regulations, Part 141, maximum contaminant levels

${ }^{d}$ Common laboratory contaminants

Milligrams per liter

Proposed Resource Conservation and Recovery Act, Subpart S, action levels

Resource Conservation and Recovery Act

${ }^{h}$ Resource Conservation and Recovery Act maximum contaminant levels

PicoCuries per liter

${ }^{1}$ The average annual concentration of beta particle and photon radioactivity from man-made radionuclides in drinking water shall not produce an annual dose equivalent to the total body or any internal organ greater than 4 millirem per year (mrem/yr). (For example, an average annual concentration of $20,000 \mathrm{pCi} / L$ of tritium firoduces a total body dose of $4 \mathrm{mrem} / \mathrm{yr}$.)

\section{B.1.3 1990 Resistivity Investigation}

In connection with suspected contaminant migration from the DPF, Engineering Science conducted a resistivity survey for REECo in March 1990 to attempt to evaluate the extent of the migration (ES, 1990). The survey consisted of a dense net of profiling stations which provided data to map lateral variations in resistivity and nine soundings to determine vertical variations. The results of the survey were interpreted to suggest the presence of contaminant migration from 
below the eastern corner of the DPF as well as several other areas of low resistivity on the northwest, northeast, and southeast sides of the DPF. However, it is suggested in the report of results on the investigation, that the results (and thus the models) used to indicate the potential presence of subsurface anomalies near the edge of the pond are likely to be invalid due to the influence of the pond on the survey. It is also stated that the presented results are simply models with no specific geologic control. As with many geophysical methods, many sources of error can affect the results and their interpretation, and without actual subsurface investigations, the results can only be used to suggest possible areas of low resistivity that might represent fluid migration from the pond (see ES, 1990 for additional information on potential sources of error).

In 1990 (REECo, 1991a), a subsurface investigation was conducted in the area of the DPF and included at least one boring (Boring $3 \mathrm{~A}$ ) in the area of the one of the resistivity soundings (see Section B.1.4). The results of this investigation were interpreted by REECo to suggest the presence of a capillary fringe zone. However, because of a lack of correlation of depths of potential geophysical anomalies and observed subsurface conditions, the study appears to have failed to confirm the results of the resistivity investigation. The resistivity investigation suggested the presence of soil with higher moisture contents from near the surface to approximately $46 \mathrm{~m}(150 \mathrm{ft})$ below ground surface which was not indicated in the observed subsurface conditions.

As stratigraphic information is obtained for the site during the characterization activities, it may be compared with the results of the survey in order to evaluate possible correlation of the resistivity data with actual subsurface data.

\section{B.1.4 1990 Preliminary Evaluation}

In order to further investigate the presence of a potential perched water zone indicated by the 1990 resistivity investigation (see Section B.1.3) and to characterize the proposed site of a new decontamination pond, an exploratory borehole program was conducted from October 29 to November 9, 1990 (REECo, 1991a). Five shallow exploratory boreholes were drilled to the south of the DPF in order to define the subsurface conditions in the area. The locations of the boreholes with respect to the DPF are shown on Figure B-1. Negligible soil moisture was observed in three of the boreholes. In Borehole $3 \mathrm{~A}$ (located near the position of the resistivity sounding S5 discussed in Section B.1.3), at a terminal depth of $21 \mathrm{~m}(69 \mathrm{ft})$, moist soil was observed on the auger, but free water was not observed. No geotechnical or hydrologic testing was conducted on the soil in order to quantify the soil properties or the actual moisture content. 
The $3 \mathrm{~A}$ borehole was not advanced beyond $21 \mathrm{~m}(69 \mathrm{ft})$, and site characterization activities at the site were abandoned. Although the data were inconclusive, the decision was made not to locate a new decontamination pond adjacent to the LPF as shown in Figure B-1.

Soil samples were also collected from the boreholes to identify any hazardous waste or manmade radionuclides under the proposed site of the new decontamination pond. Using a photoionization detector for field screening of samples, VOC levels up to 200 parts per million were measured in Boreholes 3 and 3A. Radiological measurements of 100 to 150 counts per minute (cpm), which are considered to be background levels for the Yucca Lake area, were obtained in the breathing zone, the drill cuttings, split-spoon samples, and auger (REECo, 1991a). The measurements were taken using a pancake probe. The results of laboratory analysis of the samples collected from the boreholes are presented in Table B-3.

As part of the evaluation, DPF water samples were also collected and analyzed for VOCs and radioactivity for comparison to levels detected in the soil samples. Pond-water VOC analysis detected only acetone (a common laboratory contaminant) at 42 micrograms per liter. Radiological analyses detected only iodine-131 at a concentration of $3 \times 10^{-7}$ microcuries per milliliter. Data collected during the exploratory borehole program were not adequate to confirm the presence or absence of a perched water zone migration pathway or to determine if chemicals of potential concern have migrated from the DPF (REECo, 1991a).

Although the increased moisture content observed at the bottom of boring $3 \mathrm{~A}$ could represent the capillary fringe of a perched water zone, this is only one possible interpretation (e.g., wetting front or natural variation in soil moisture are other possibilities). Furthermore, visual observation of soil conditions in the area and sampling and preliminary sample analysis of soil collected from other nearby areas of Yucca Lake (i.e., the Area 6 Sewage Lagoons) suggest that the clay content of the soil would result in a hydraulic conductivity of $10^{-6}$ centimeters/second or less. This being the case, if there were to be a perched water zone at a depth of greater than $21 \mathrm{~m}(69 \mathrm{ft})$, the water would have required at least 67 years to reach this depth with saturated soil conditions and a constant head (both of which are unlikely) when traveling straight downward from the surface. Another possibility is that the water could have entered the lake-bed sediments from the interface between the playa deposits and the surrounding alluvial deposits at depth. In either case, infiltration from the DPF would not be sufficient to account for the presence of a perched water zone at the suggested depth. 


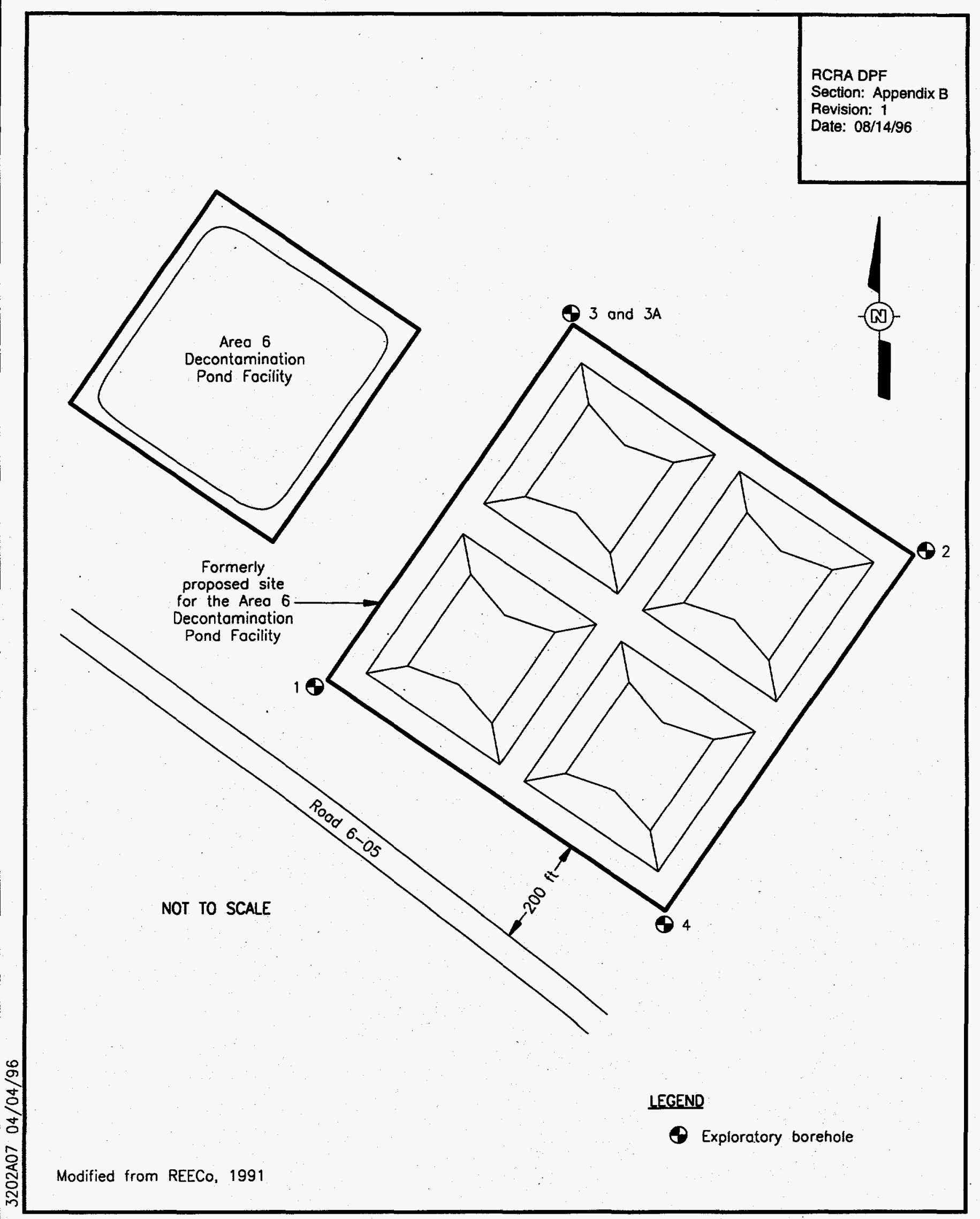

Figure B-1

Exploratory Borehole Locations Near the Area 6 Decontamination Pond Facility 
Table B-3

\section{Summary of Laboratory Results from the 1990 Preliminary Evaluation ${ }^{\mathrm{a}}$}

\begin{tabular}{|c|c|c|c|}
\hline \multirow[b]{2}{*}{ Soil Sample Location } & \multicolumn{3}{|c|}{ Detected Constituents of Concern } \\
\hline & Acetone & $\begin{array}{c}\text { Methylene } \\
\text { Chloride }\end{array}$ & Radionuclides $^{b}$ \\
\hline Borehole 1 - Composite $^{c}$ & $N D^{d}$ & ND & ND \\
\hline Borehole 2 - Composite $^{c}$ & ND & ND & ND \\
\hline Borehole 3 - Composite $^{c}$ & $342 \mu \mathrm{g} / \mathrm{kg}^{\mathrm{e}}$ & $116 \mu \mathrm{g} / \mathrm{kg}$ & ND \\
\hline Borehole 3A - Composite ${ }^{c}$ & $200 \mu \mathrm{g} / \mathrm{kg}$ & ND & ND \\
\hline Borehole 4 - Composite ${ }^{c}$. & ND & $42 \mu \mathrm{g} / \mathrm{kg}$ & ND \\
\hline Pond Water & $42 \mu \mathrm{g} / \mathrm{mL}^{f}$ & ND & $3 \times 10^{-7} \mu \mathrm{Ci} / \mathrm{mL}^{9}$ \\
\hline
\end{tabular}

Adapted from REECo, 1991a

lodine-131

'Soil samples were composited taken at the following depthts:

Borehole 1 subsamples: $13.5,33.5,53.5$, and 73.5 feet, respectively

Borehole 2 subsamples: $8.5,18.5,33.5$, and 48.5 feet, respectively

Borehole 3a subsamples: $38.5,43.5$, and 48.5 feet, respeictively

Borehole 3 subsamples: $8.5,28.5,33.5$, and 38.5 feet, respectively

Borehole 4 subsamples: $8.5,18.5,28.5$, and 48.5 feet, respectively

${ }^{d} \mathrm{ND}=$ Not detected

Micrograms per kilogram

Micrograms per milliliter

${ }^{9}$ Microcuries per milliliter

\section{B.1.5 1991 Release Evaluation}

To determine what chemicals of potential concern may have been released onto the playa as a result of a March 3, 1991, release from the DPP, it has been suggested by BN personnel (former REECo personnel) that the REECo Health Physics Department collected pond-water samples on March 4 and March 5, 1991, for water quality analyses. However, no formal documentation of the sampling and analysis has been found and no report of findings was published on the results of the sampling.

\section{B.1.6 1994 Preliminary Evaluation}

In September 1994, IT Corporation conducted a preliminary sampling event at the DPF (IT, 1995). Soil/sediment samples were obtained from three locations within the pond: one on the pond berm, one in the 1991 spill area, and one from a background (i.e., uncontaminated) area. The samples were analyzed for total VOCs and SVOCs, toxicity characteristic (TC) metals, total petroleum hydrocarbons (TPH), and radionuclides.

For the samples from the pond interior, the results of the analyses indicated the presence of elevated levels of TPH in five samples and a field duplicate $(115$ to $5,490 \mathrm{mg} / \mathrm{kg}$ ). However, 
since EPA Method 418.1 (EPA, 1986) was used for the TPH analysis, it is likely that the results of analyses using EPA Method 8015 modified (EPA, 1986) or its equivalents (as required by regulation) would be lower than these levels. However, the levels would probably still be above the regulatory action level of $100 \mathrm{mg} / \mathrm{kg}$ in the higher concentration samples. Elevated concentrations of chlorobenzene were observed in two samples and a field duplicate $(32,36$, and $79 \mu \mathrm{g} / \mathrm{kg}$, respectively) from within the pond. Elevated levels of gross beta, cobalt-60 (1.6 to $120 \mathrm{pCi} / \mathrm{g}$ in three samples, one field duplicate, and laboratory duplicate) and americium-241 ( $0.85 \mathrm{pCi} / \mathrm{g}$ in one sample) were also observed from samples obtained within the pond. Thallium-208 was observed ranging from 0.57 to $0.70 \mathrm{pCi} / \mathrm{g}$ in three samples from within the pond, one sample in the 1991 spill area, and in the background sample. The location of the samples are shown on Figure B-2, and the results of the analyses are summarized on Table B-4.

\section{B.1.7 1994 Geophysical Evaluation}

In October and November 1994, a geophysical investigation was conducted at the DPF (IT, 1996) with the following objectives:

- Determine if leachate migration away from the pond has occurred.

- Approximate the lateral boundaries and vertical extent of any plume present in the shallow subsurface.

- Locate shallow conductive zones in the vicinity of the ponds potentially representing perched leachate.

To accomplish these objectives, electromagnetic (EM) induction surveys were conducted at various transmitter/receiver intercoil spacings and system configurations, which provided for a qualitative interpretation of changing physical conditions with depth beneath the surface. Interpretation of the results of the survey suggested possible subsurface fluid/leachate migration away from the DPF in a southeast direction as well as in the area of a release that occurred from the pond piping. However, surface conditions and subsurface utilities in the area of the DPF (i.e., fencing) may have skewed some of the data values (particularly those nearest the DPF), resulting in an inaccurate interpretation of subsurface conditions. Subsurface investigation and sampling will be necessary to confirm the results of the geophysical evaluation. 


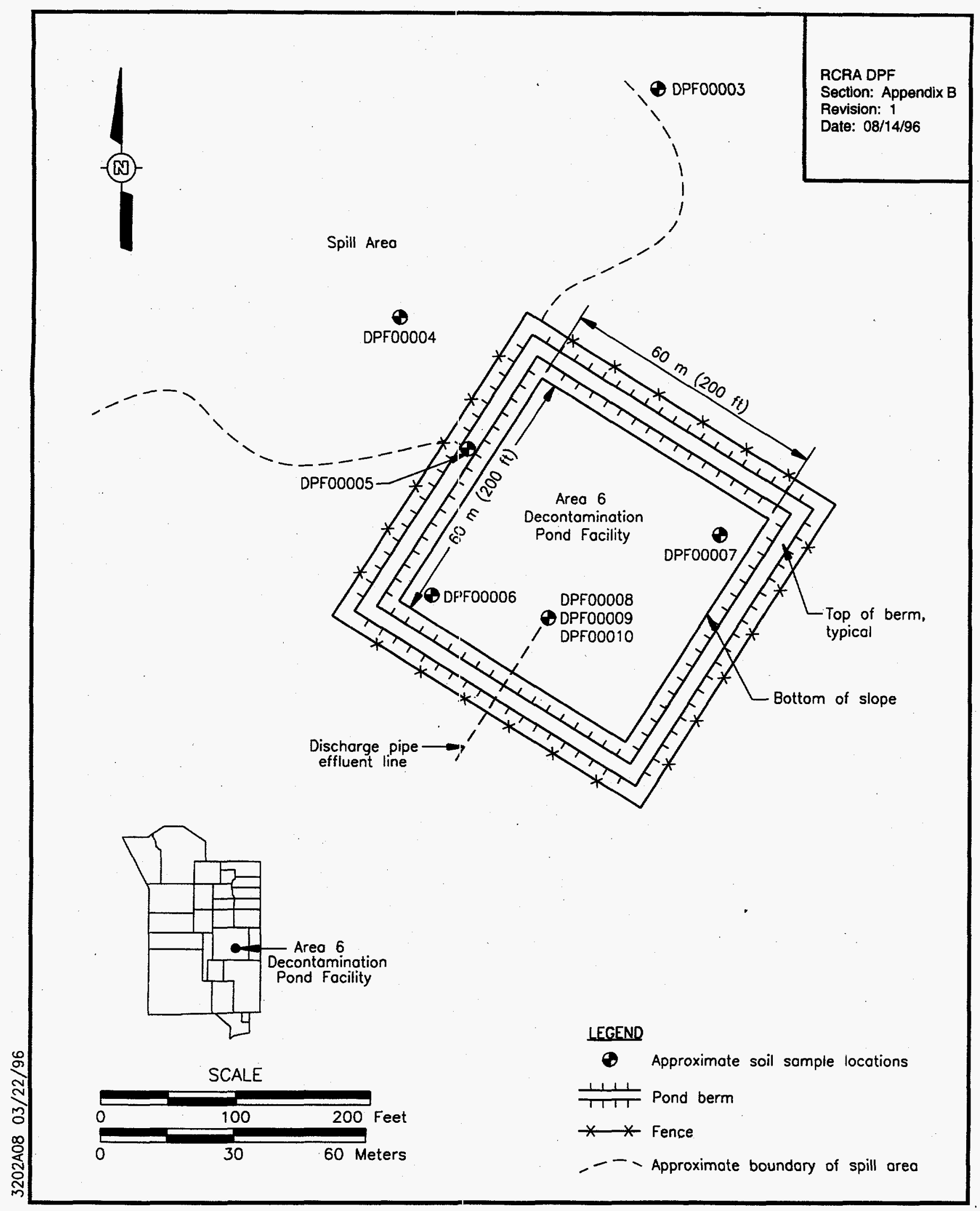

Figjure B-2

1994 Preliminary Soil Sample Locations

Area 6 Decontamination Pond Facility

B-8 


\section{$T$}

Detected Constituents of Co
Sampling of the Area 6

\begin{tabular}{|c|c|c|c|c|c|c|c|}
\hline \multicolumn{4}{|c|}{ Sample Number } & DPF00003 & DPF00004 & DPF00005 & DPI \\
\hline Parameter & Units & $\mathrm{DL} / \mathrm{MDA}^{\mathrm{a}}$ & RLAL $^{b}$ & Background & Spill Area & Top of Berm & $\begin{array}{l}\text { West Co } \\
\text { Pond }\end{array}$ \\
\hline$T^{d}$ Barium & $\mathrm{mg} / \mathrm{L}^{e}$ & 0.20 & 100 & 0.23 & ND' & 0.52 & \\
\hline TC Cadmium & $\mathrm{mg} / \mathrm{L}$ & 0.005 & 1.0 & ND & ND & ND & \\
\hline Chlorobenzene & $\mu \mathrm{g} / \mathrm{kg}^{\mathrm{h}}$ & 6 & $D L$ & ND & ND & ND & \\
\hline $\mathrm{TPH}^{\mathrm{i}}$ & $\mathrm{mg} / \mathrm{kg}^{\mathrm{j}}$ & $0.49-630$ & 100 & ND & ND & ND & \\
\hline Gross Alpha & $\mathrm{pCi} / \mathrm{g}^{\mathrm{k}}$ & $<2.2$ & $A B^{\prime}$ & 13.8 & 12.8 & 20 & \\
\hline Gross Beta & $\mathrm{pCi} / \mathrm{g}$ & $<2$ & $A B$ & 30.4 & 29.4 & 28.2 & \\
\hline$K-40$ & $\mathrm{pCi} / \mathrm{g}$ & $<3.8$ & NA & 25.7 & 23.3 & 29.0 & \\
\hline Co-60 & $\mathrm{pCi} / \mathrm{g}$ & $<1$ & $500^{*}$ & ND & ND & ND & \\
\hline Cs-137 & $\mathrm{pCi} / \mathrm{g}$ & $<0.8$ & $3^{*}$ & ND & ND & ND & \\
\hline TI-208 & $\mathrm{pCi} / \mathrm{g}$ & $<0.23$ & $N A^{*}$ & 0.57 & 0.49 & ND & \\
\hline $\mathrm{Pb}-212$ & $\mathrm{pCi} / \mathrm{g}$ & $<0.67$ & NA & 1.82 & 1.76 & 2.31 & \\
\hline $\mathrm{Pb}-214$ & $\mathrm{pCi} / \mathrm{g}$ & $<0.33$ & NA & 1.05 & ND & 1.10 & \\
\hline Ra-226 & $\mathrm{pCi} / \mathrm{g}$ & $<0.41$ & NA & 0.98 & ND & ND & \\
\hline Ra-228 & $\mathrm{pCi} / \mathrm{g}$ & $<0.59$ & NA & ND & ND & 1.93 & \\
\hline Am-241 & $\mathrm{pCi} / \mathrm{g}$ & 0.23 & $N A^{*}$ & ND & ND & ND & \\
\hline
\end{tabular}

Note: bold text indicates concentrations exceeding regulatory or other applicable limits

*The indicated radionuclides (possible or likely man-made) indicate potential impact when present above the MDA but ${ }^{a}$ Detection limit/minimum detectable activity

${ }^{b}$ Quantitative regulatory limit (NDEP, 1992; BN, 1996; 40 CFR Part 761)/qualitative action level

${ }^{\mathrm{C} B e l o w}$ ground surface

${ }^{\mathrm{D}}$ Toxicity Characteristic

Milligrams/liter

'Not detected

${ }^{9}$ Not applicable

hMicrograms/kilogram

'Total petroleum hydrocarbons by EPA Method 418.1

Milligrams/kilogram

${ }^{k}$ PicoCuries/gram

'Elevated above average background (Adams, 1996) 


\section{e B-4}

\section{ern for the 1994 Preliminary Soil contamination Pond Facility}

\begin{tabular}{|c|c|c|c|c|c|}
\hline DPF00007 & DPF00008 & DPF00008DLP & DPF00009 & DPF00010 & DPF00011 \\
\hline East Corner of Pond & $\begin{array}{l}\text { Pond Outflow Pipe - } \\
18^{\prime \prime} \mathrm{bgs}^{\mathrm{c}}\end{array}$ & Laboratory Duplicate & $\begin{array}{l}\text { Field Duplicate of } \\
\text { DPF00008 }\end{array}$ & $\begin{array}{l}\text { Pond Outflow Pipe - } \\
24^{\prime \prime} \text { bgs }\end{array}$ & $\begin{array}{l}\text { Pond Outflow Pipe } \\
36^{\prime \prime} \text { bgs }\end{array}$ \\
\hline 0.33 & 0.33 & $N A^{g}$ & 0.36 & ND & 0.32 \\
\hline ND & 0.088 & NA & 0.019 & ND & ND \\
\hline 32 & 36 & NA & 79 & ND & ND \\
\hline 124 & 4,090 & NA & 5,490 & 519 & 115 \\
\hline 17.5 & 15.0 & 22.2 & 19.2 & 13.6 & 8.57 \\
\hline 31.7 & 93.2 & 109 & 97.1 & 32.6 & 23.4 \\
\hline 31.7 & 31.6 & 28.5 & 23.8 & 29.4 & 16.6 \\
\hline 1.6 & 34.1 & 33.7 & 120 & 2.05 & ND \\
\hline 0.98 & 10.3 & 9.54 & 34.1 & 0.99 & ND \\
\hline 0.70 & ND & ND & ND & 0.66 & ND \\
\hline 2.33 & 1.78 & 1.84 & ND & 2.06 & 1.37 \\
\hline 1.13 & ND & ND & ND & ND & ND \\
\hline 1.02 & ND & ND & ND & ND & ND \\
\hline ND & ND & ND & ND & ND & ND \\
\hline ND & ND & 0.85 & ND & ND & ND \\
\hline
\end{tabular}

$y$ be unregulated at that level 
In comparison to the results of the 1990 resistivity survey, there appears to be little to no correlation between the results of the two investigations. This is likely to have been caused by the different methods and evaluation techniques used to interpret the raw data. The lack of correlation reaffirms the inherent uncertainty involved in the use of geophysical evaluations when there is little geologic control available. When the results of the 1990 subsurface investigation are considered (see Section B.1.4), it is possible to see that there is no indication in the geophysical results of a perched water zone or any other subsurface anomaly in the area of the 1 or $3 \mathrm{~A}$ borings. However, the geophysics can be interpreted to confirm the presence of a uniform section of sediment, as observed in the borings.

\section{B.1.8 1996 Preliminary Evaluation}

In March 1996, IT conducted a preliminary evaluation of the DPF. The results of this preliminary evaluation were not available for this plan, but they will be important in determining the distribution of contaminants at the surface and the COCs present in the soil. The final results of the preliminary evaluation will be provided in the characterization report for the site. Presented in this section are the data collected and, at least, preliminary interpretations of the data. The final planning and implementation of subsequent characterization phases will be based on the results of these preliminary characterization activities. It is expected that the conceptual model for the site will also be refined based on the results of this preliminary evaluation.

The March 1996 preliminary evaluation consisted of a field radiological survey and a systematic random surface soil sampling. These activities were conducted in order to help refine the conceptual model for the site prior to initiating subsurface soil sampling by identifying the COCs for the site and potentially limiting the lateral extent of subsequent characterization activities.

\section{B.1.8.1 Field Radiologic Surveying}

A field radiologic survey was conducted by IT on March 25 and 26, 1996, of the DPF and the associated spill area. The survey was based on a superimposed surveyed site grid (and divisions thereof) (Figure B-3) and used portable, large volume scintillation detectors (Eberline ESP2 instruments with 7.62 - by 7.62 -centimeter [3- by 3 -inch] sodium iodide [ $\mathrm{NaI}$ ] detectors) for a walk-over type survey. Count rate measurements were collected on the ground surface at each grid node and marked as soil sample locations. These count rates were recorded on the appropriate field forms. At one corner of each subdivided grid block, the detector scaler integrated the total counts. The entire subdivided grid block was surveyed at a steady rate (approximately two feet per second), beginning along one side and covering the entire block in a 


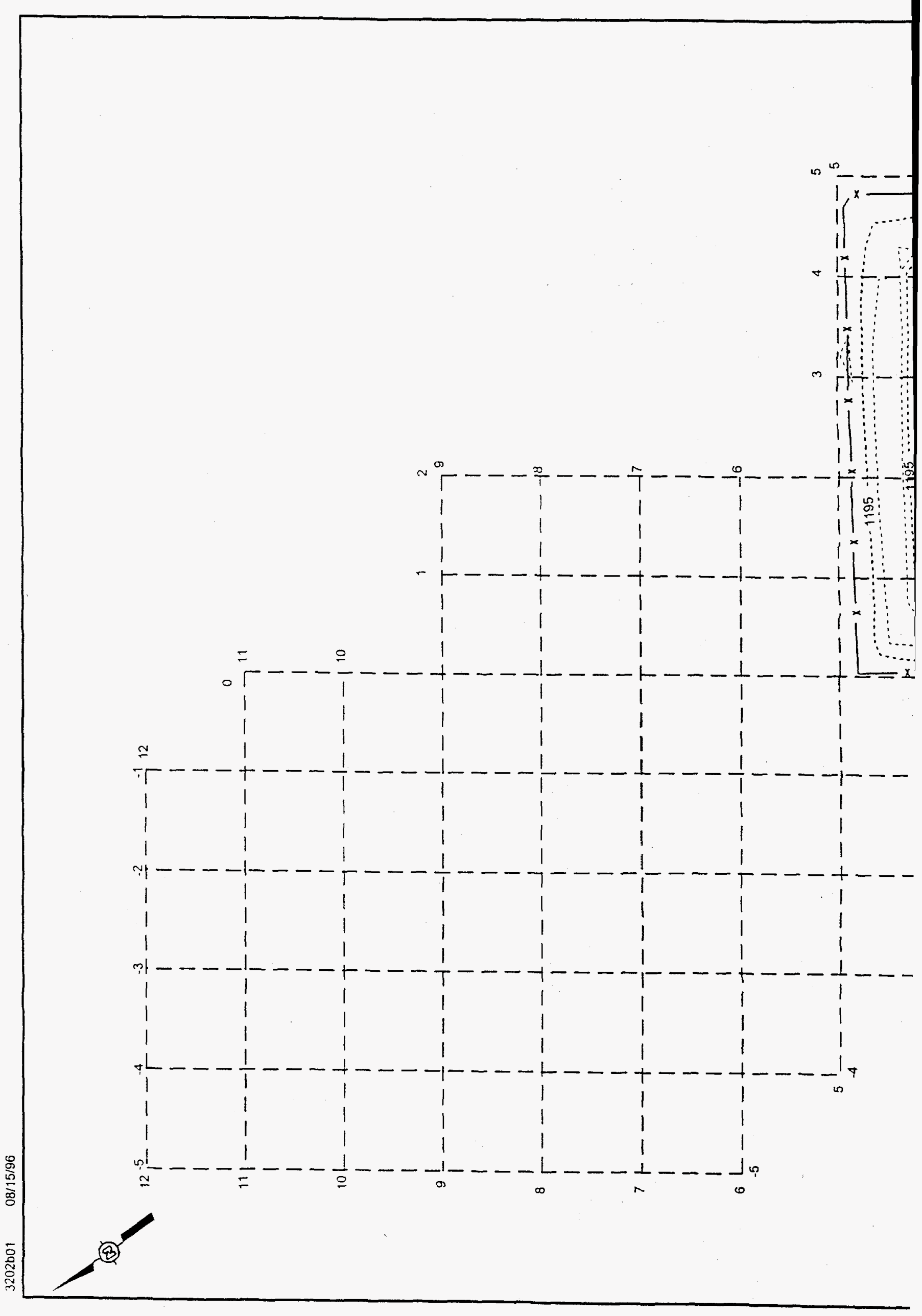




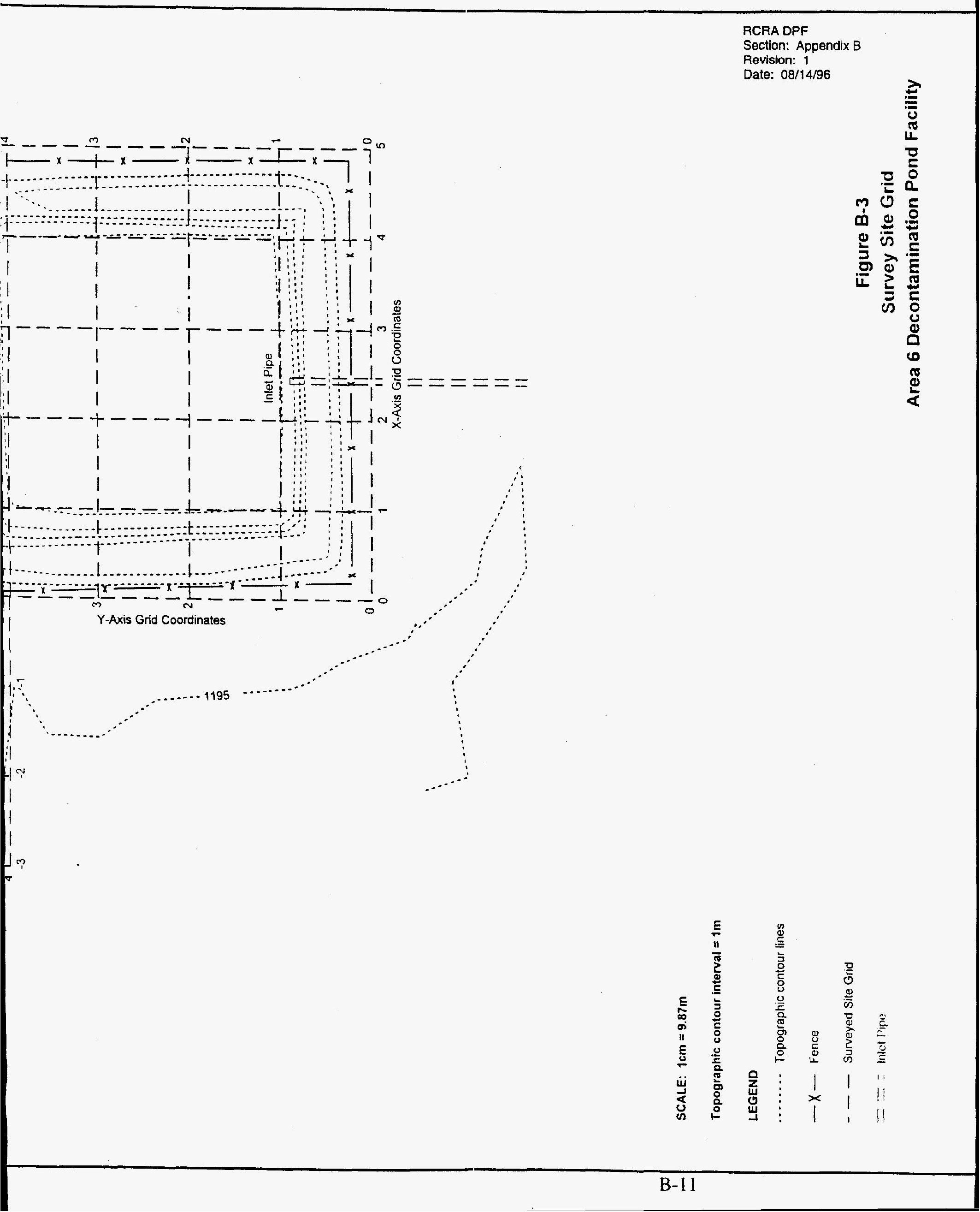


rectangular fashion until all areas were surveyed. The scintillation probe was suspended by a rope or strap and swung from side-to-side in a serpentine fashion for the survey, and the survey meter count rate was continuously monitored. Any area with a localized elevated count rate was marked, and the survey was continued at the same pace. After the walk-over of the grid was completed, the scaler and timer were stopped, and the total count was recorded on the field forms.

Any location marked as elevated during the walk-over was systematically surveyed beginning at the survey mark and working outward to determine the areal extent of the elevated readings. The approximate location and areal extent of all elevated areas were recorded, and markers were placed at the location of the highest readings.

The results of the survey were evaluated for statistical adequacy through analysis of the data mean and standard deviation with respect to the evaluation of sample population requirements based on the equations supplied in Chapter 9 of SW-846 (EPA, 1986). For surface radiation surveys such as the one conducted here, the walk-over survey is typically thought to be a more accurate measurement of the surface radiation than the static measurements taken at the grid nodes. Using the SURFER computer contouring program to model the data, it also appears that the walk-over data results in a more realistic contouring of the surface radiation at the site than maps that either use the static measurements or combine the static and walk-over measurements. Using this information, the results suggest the presence of two areas of higher potential radioactive contamination, one concentrated around the inlet pipe and the other directly across the pond to the east-northeast (see Figure B-4). The results also suggest that, in comparison to background levels taken from outside of the pond, the entire interior surface of the pond has radiation levels elevated above background. However, the entire area directly around the pond does not appear to have radiation levels that are elevated above background with the possible exception of one small area near the north corner of the pond. Figure B-4 shows the modeled configuration of the radiation levels in and around the pond. Further evaluation of these results will be included in the characterization report for the site.

\section{B.1.8.2 Surface Soil Sample Collection}

Samples for COC analysis were collected by IT on March 26 and 27, 1996, from gridded sample locations within and adjacent to the DPF (Figure B-5). Soil samples were retrieved from a depth of 0 to 5.2 centimeters ( 0 to 6 inches) at each of the designated sample locations using a decontaminated, disposable or stainless steel scoop. A quantity of soil was collected for off-site 


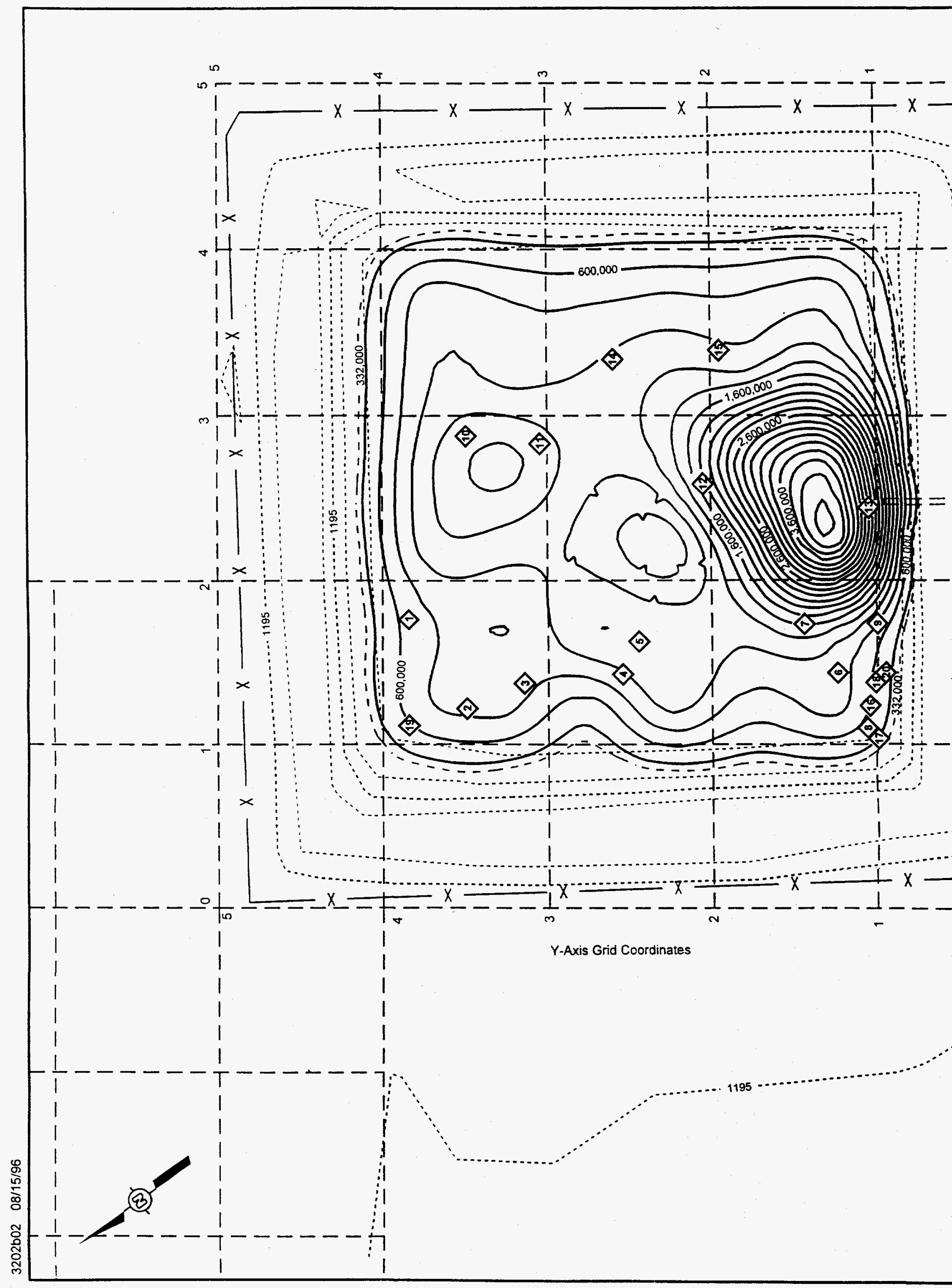




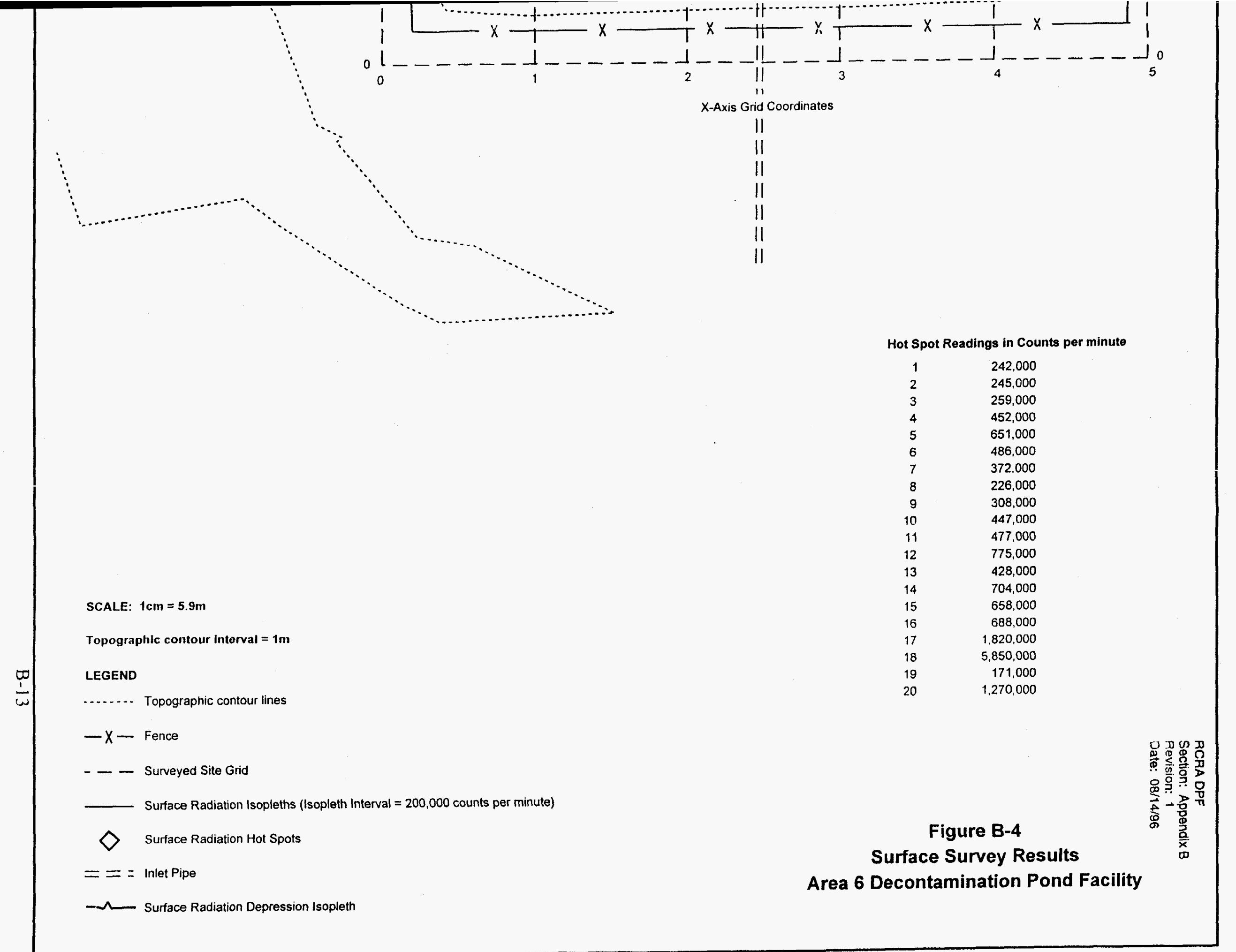




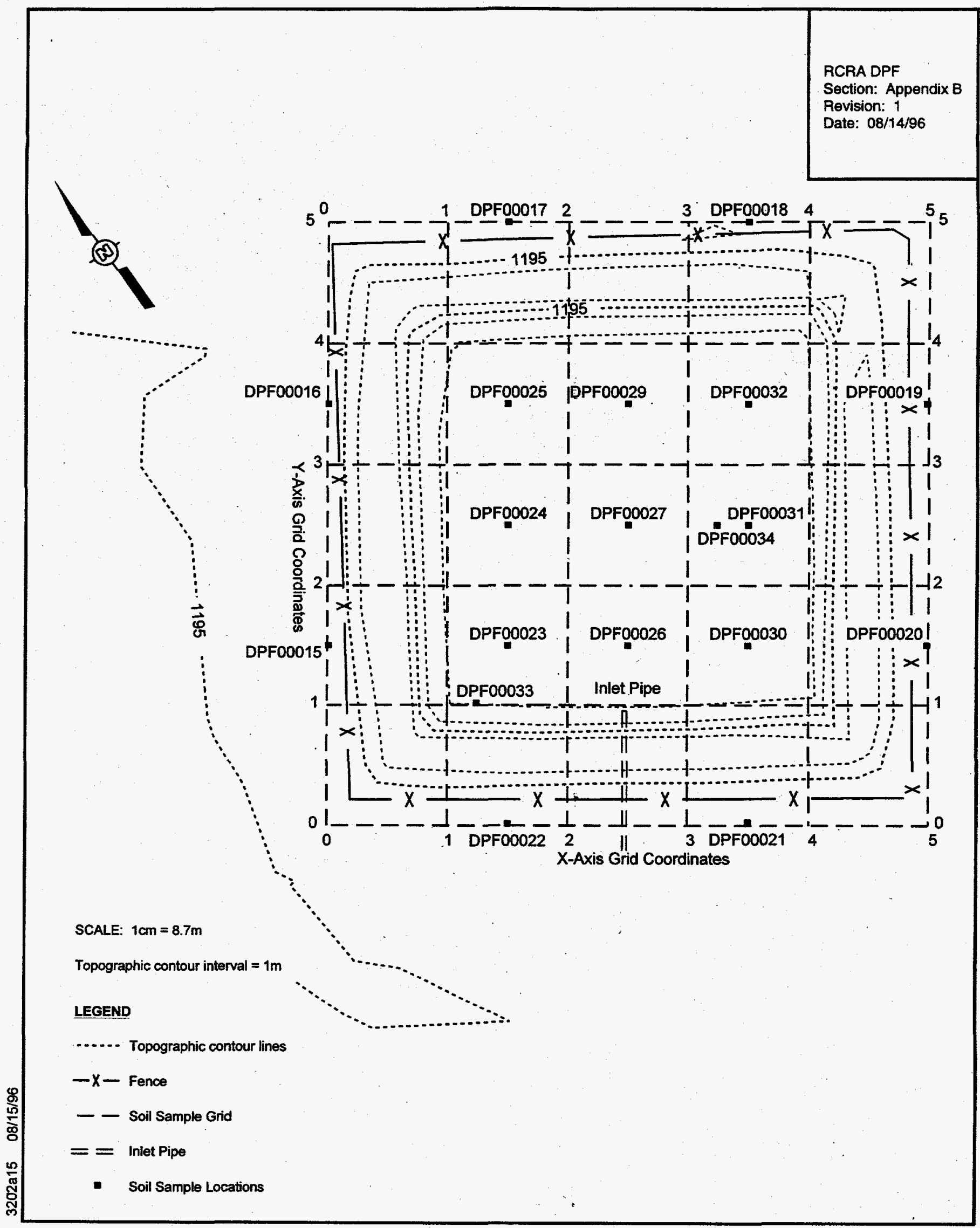

Figure B-5

March 1996 Surface Soil Sample Locations

Area 6 Decontamination Pond Facility

B-14 
analysis of each sample. The samples were placed in the appropriate sample jars or sleeves and immediately sealed, labeled, and placed in iced coolers or a refrigerator. Samples were collected to document contaminant types and concentrations and to identify potentially impacted and unimpacted areas.

All samples collected were analyzed by an approved off-site laboratory (i.e., Quanterra Environmental Services) for the parameters listed in Table B-5. Additional analyses for isotopic plutonium and strontium-89/90 were conducted as a result of the elevated levels of gross alpha and beta detected in the original analysis of the samples. The results of these analyses were not available for this document. A total of 19' samples (plus the required quality control samples) were obtained from the DPF based on the current conceptual model and grid pattern and decisions made in the field. The COCs detected during the sample analysis are presented in Table B-6. These results indicate the presence of only TPH and radionuclide contamination at the surface of the site. No RCRA-regulated constituents were detected above action levels or detection limits, as applicable. Additional information and interpretation of the sampling results, including quality control data analysis, will be provided in the characterization report to be prepared for the site upon completion of all characterization activities. 
Table B-5

March 1996 Preliminary Evaluation Analytical Methods

\begin{tabular}{|c|c|c|}
\hline Media & Analytiçal Parameter & Analytical Method ${ }^{a}$ \\
\hline \multirow{13}{*}{ Surface Soil } & Total Petroleum Hydrocarbons (TPH) & EPA 8015 Modified \\
\hline & Total Volatile Organic Compounds (VOCs) & EPA 8240 \\
\hline & Toxicity Characteristic (TC) VOCs & EPA $1311 / 8240$ \\
\hline & Total Semi-Volatile Organic Compounds (SVOCs) & EPA 8270 \\
\hline & TC SVOCs & EPA 1311/8270 \\
\hline & $\begin{array}{l}\text { TC Metals: (Arsenic, Barium, Cadmium, } \\
\text { Chromium, Lead, Selenium, Silver) } \\
\text { TC Metals: Mercury }\end{array}$ & $\begin{array}{l}\text { EPA } 1311 / 6010 \\
\text { EPA } 1311 / 7470\end{array}$ \\
\hline & TC Pesticides & EPA $1311 / 8080 A$ \\
\hline & TC Herbicides & EPA $1311 / 8150$ \\
\hline & Polychlorinated Biphenyls & EPA 8020 \\
\hline & Isotopic Plutonium & NAS-NS3058 ${ }^{b}$ \\
\hline & Strontium $89 / 90$ & Sr- $7500^{c}$ \\
\hline & Gross Alpha/Beta & $\operatorname{SM} 7110^{d}$ \\
\hline & Gamma Spectroscopy & HASL $300,4.5 .2 .3^{\mathrm{e}}$ \\
\hline
\end{tabular}

\footnotetext{
${ }^{a}$ SW-846 (U.S. Environmental Protection Agency [EPA], 1986) unless otherwise noted

National Academy of Science, Nuclear Series (Coleman, 1965)

CAlpha Inc., 1960

Standard Methods for the Examination of Water and Waste Water (APHA, 1992)

Environmental Measurements Laboratory Procedure Manual, HASL-300 (DOE, 1992a)
} 
$T e$
cer

Detected Constituents of Concer
Sampling of the Area 6

\begin{tabular}{|c|c|c|c|c|c|c|c|}
\hline \multicolumn{4}{|c|}{ Sample Number } & DPF00015 & DPF00016 & DPF00017 & DPF000 \\
\hline Parameter & Units & DLMMDA $^{a}$ & $R L / A L^{b}$ & \multicolumn{4}{|r|}{ Pond } \\
\hline $\mathrm{TC}^{\mathrm{C}}$ Barium & $\mathrm{mg} / \mathrm{L}^{\mathrm{d}}$ & 0.80 & 100 & 0.85 & $(0.48)$ & 0.96 & $(0.73)$ \\
\hline TC Cadmium & $\mathrm{mg} / \mathrm{L}$ & 0.020 & 1.0 & $N^{e}$ & ND & ND & ND \\
\hline TC Mercury & $\mathrm{mg} / \mathrm{L}$ & $0.0002 / 0.0008$ & 0.20 & ND & ND & ND & ND \\
\hline $\mathrm{PCBs}^{i}$ & $\mu \mathrm{g} / \mathrm{kg}^{\mathrm{g}}$ & 33 & 50,000 & ND & ND & ND & ND \\
\hline $\mathrm{TPH}^{\mathrm{h}}$ & $\mathrm{mg} / \mathrm{kg}^{\mathrm{i}}$ & $25-2,500$ & 100 & ND & ND & ND & ND \\
\hline Gross Alpha & $\mathrm{pCi} / \mathrm{g}^{\mathrm{j}}$ & $\geq 4.4$ & $A B^{k}$ & 16.2 & 12.5 & 14.4 & 17.3 \\
\hline Gross Beta & $\mathrm{pCi} / \mathrm{g}$ & $\geq 3.0$ & $A B$ & 36.1 & 27.9 & 32.0 & 33.1 \\
\hline$K-40$ & $\mathrm{pCi} / \mathrm{g}$ & $\geq 11.6$ & $N A^{\prime}$ & 30.4 & 27.3 & 29.9 & 30.4 \\
\hline Co-60 & $\mathrm{pCi} / \mathrm{g}$ & $\geq 1.0$ & $500^{*}$ & ND & ND & ND & ND \\
\hline Cs-137 & $\mathrm{pCi} / \mathrm{g}$ & $\geq 1.6$ & $3^{*}$ & ND & ND & ND & ND \\
\hline TI-208 & $\mathrm{pCi} / \mathrm{g}$ & $\geq 0.53$ & $N A^{*}$ & 0.65 & 0.59 & 0.66 & 0.68 \\
\hline $\mathrm{Pb}-212$ & $\mathrm{pCi} / \mathrm{g}$ & $\geq 1.04$ & NA & 2.29 & 2.09 & 2.53 & 2.35 \\
\hline $\mathrm{Bi}-212$ & $\mathrm{pCi} / \mathrm{g}$ & $\geq 2.15$ & NA & ND & ND & ND & ND \\
\hline $\mathrm{Pb}-214$ & $\mathrm{pCi} / \mathrm{g}$ & $\geq 0.84$ & NA & 1.34 & 1.72 & 2.10 & 1.00 \\
\hline Bi-214 & $\mathrm{pCi} / \mathrm{g}$ & $\geq 1.67$ & NA & 1.37 & ND & 1.37 & ND \\
\hline $\mathrm{Ra}-226$ & $\mathrm{pCi} / \mathrm{g}$ & $\geq 1.06$ & NA & 1.41 & 1.36 & 1.41 & 1.18 \\
\hline $\mathrm{Ra}-228$ & $\mathrm{pCi} / \mathrm{g}$ & $\geq 1.06$ & NA & 2.10 & ND & 2.11 & 2.22 \\
\hline Am-241 & $\mathrm{pCi} / \mathrm{g}$ & $\geq 0.57$ & $\mathrm{NA}^{*}$ & ND & ND & ND & ND \\
\hline
\end{tabular}




\section{le B-6}

\section{for the 1996 Preliminary Surface Soil contamination Pond Facility}

\begin{tabular}{|c|c|c|c|c|c|c|}
\hline DPF00019 & DPF00020 & DPF00021 & DPF00022 & DPF00023 & DPF00024 & DPF00025 \\
\hline Samples & & & & \multicolumn{3}{|c|}{ Pond Interior Samples } \\
\hline$(0.48)$ & 0.82 & $(0.78)$ & $(0.74)$ & $(0.32)$ & $(0.49)$ & $(0.38)$ \\
\hline ND & ND & ND & $(0.011)$ & 0.098 & 0.032 & 0.021 \\
\hline ND & ND & ND & ND & 0.0006 & 0.0007 & 0.0007 \\
\hline ND & ND & ND & ND & 300 & 240 & 210 \\
\hline ND & ND & ND & ND & 18,000 & 3,200 & 7,600 \\
\hline 18.7 & 16.0 & 12.5 & 12.7 & 42.6 & 14.5 & 19.8 \\
\hline 35.6 & 35.9 & 32.9 & 31.6 & 367 & 91.2 & 124 \\
\hline 23.8 & 30.6 & 29.8 & 29.4 . & 22.4 & 30.3 & 19.7 \\
\hline ND & ND & ND & ND & 55.0 & 111 & 49.9 \\
\hline ND & ND & ND & ND & 23.2 & 25.3 & 21.0 \\
\hline 0.62 & 0.85 & 1.09 & 0.88 & ND & ND & ND \\
\hline 1.99 & 2.20 & 2.02 & 2.23 & 2.07 & ND & ND \\
\hline ND & 2.77 & ND & ND & ND & ND & ND \\
\hline ND & 1.58 & 1.37 & 1.39 & ND & ND & ND \\
\hline ND & ND & ND & 1.41 & ND & ND & ND \\
\hline 1.33 & 1.60 & 1.16 & 1.42 & ND & ND & ND \\
\hline ND & 2.09 & ND & 2.40 & ND & ND & ND \\
\hline ND & 3.08 & ND & ND & ND & 4.10 & ND \\
\hline
\end{tabular}


Table B

Detected Constituents of Concer Sampling of the Area 6

\begin{tabular}{|c|c|c|c|c|c|c|}
\hline \multicolumn{4}{|c|}{ Sample Number } & DPF00026 & DPF00027 & DPF00027DUP \\
\hline Parameter & Units & DL/MDA & RLALL & & & \\
\hline TC Barium & $\mathrm{mg} / \mathrm{L}$ & 0.80 & 100 & $(0.41)$ & $(0.24)$ & NA \\
\hline TC Cadmium & $\mathrm{mg} / \mathrm{L}$ & 0.020 & 1.0 & 0.26 & $(0.011)$ & NA \\
\hline TC Mercury & $\mathrm{mg} / \mathrm{L}$ & $0.0002 / 0.0008$ & 0.20 & 0.0007 & ND & NA \\
\hline PCBs & $\mu \mathrm{g} / \mathrm{kg}$ & 33 & 50,000 & 2,000 & ND & NA \\
\hline $\mathrm{TPH}$ & $\mathrm{mg} / \mathrm{kg}$ & $25-2,500$ & 100 & 21,000 & 350 & NA \\
\hline Gross Alpha & $\mathrm{pCi} / \mathrm{g}$ & $\geq 4.4$ & $A B$ & 114 & 19.2 & NA \\
\hline Gross Beta & $\mathrm{pCi} / \mathrm{g}$ & $\geq 3.0$ & $A B$ & 135 & 45.0 & NA \\
\hline$K-40$ & $\mathrm{pCi} / \mathrm{g}$ & $\geq 11.6$ & NA & 19.8 & 23.3 & 23.3 \\
\hline Co-60 & $\mathrm{pCi} / \mathrm{g}$ & $\geq 1.0$ & $500^{*}$ & 197 & 4.32 & 2.60 \\
\hline Cs-137 & $\mathrm{pCi} / \mathrm{g}$ & $\geq 1.6$ & $3^{*}$ & 75.5 & 1.81 & 0.89 \\
\hline TI-208 & $\mathrm{pCi} / \mathrm{g}$ & $\geq 0.53$ & $N^{*}$ & ND & 0.82 & ND \\
\hline $\mathrm{Pb}-212$ & $\mathrm{pCi} / \mathrm{g}$ & $\geq 1.04$ & NA & ND & 1.70 & 1.77 \\
\hline $\mathrm{Bi}-212$ & $\mathrm{pCi} / \mathrm{g}$ & $\geq 2.15$ & NA & ND & ND & ND \\
\hline $\mathrm{Pb}-214$ & $\mathrm{pCi} / \mathrm{g}$ & $\geq 0.84$ & NA & ND & 1.17 & 0.91 \\
\hline $\mathrm{Bi}-214$ & $\mathrm{pCi} / \mathrm{g}$ & $\geq 1.67$ & NA & ND & ND & ND \\
\hline Ra-226 & $\mathrm{pCi} / \mathrm{g}$ & $\geq 1.06$ & NA & ND & 1.01 & 0.98 \\
\hline Ra-228 & $\mathrm{pCi} / \mathrm{g}$ & $\geq 1.06$ & NA & ND & ND & NO \\
\hline Am-241 & $\mathrm{pCi} / \mathrm{g}$ & $\geq 0.57$ & $\mathrm{NA}^{*}$ & 7.54 & ND & ND \\
\hline
\end{tabular}

Note: bold text indicates concentrations exceeding regulatory or other applicable limits

Note: results in parentheses are reported below the contract-required detection limits but above the instrumer ${ }^{*}$ The indicated radionuclides (possible or likely man-made) indicate potential impact when present above the $\mathrm{A}$

${ }^{a}$ Detection limit/minimum detectable activity

bQuantitative regulatory limit (NDEP, 1992; BN, 1996; 40 CFR Part 761)/qualitative action level

${ }^{\mathrm{c}}$ Toxicity Characteristic

${ }^{\mathrm{d}}$ Milligrams/liter

${ }^{\mathrm{e}}$ Not detected

'Polychlorinated biphenyls (aroclor-1254)

${ }^{9}$ Micrograms/kilogram

${ }^{\mathrm{h}}$ Total Petroleum Hydrocarbons (in the oil range)

'Milligrams/kilogram

'PicoCuries/gram

${ }^{k}$ Elevated above average background (Adams, 1996)

Not applicable 
Continued

\section{or the 1996 Preliminary Surface Soil contamination Pond Facility}

\begin{tabular}{|c|c|c|c|c|c|c|}
\hline F00028 & DPF00029 & DPF00030 & DPF00031 & DPF00032 & DPF00033 & DPF00034 \\
\hline \multicolumn{7}{|c|}{ Pond Interior Samples } \\
\hline$(0.19)$ & $(0.29)$ & $(0.29)$ & $(0.32)$ & $(0.41)$ & $(0.23)$ & $(0.72)$ \\
\hline 0.014$)$ & ND & 0.027 & $(0.016)$ & $(0.014)$ & 0.11 & 0.027 \\
\hline ND & ND & ND & ND & $(0.0005)$ & ND & $(0.0004)$ \\
\hline 44 & 400 & 160 & 91 & 330 & 240 & 170 \\
\hline 420 & 6,300 & 5,400 & 1,700 & 9,800 & 5,200 & 2,800 \\
\hline 17.4 & 24.2 & 18.9 & 22.4 & 31.7 & 15.0 & 43.4 \\
\hline 55.9 & 282 & 94.7 & 70.5 & 152 & 50.4 & 357 \\
\hline 22.1 & 16.6 & 23.4 & ND & 21.7 & 23.8 & ND \\
\hline 17.8 & 139 & 57.4 & 18.2 & 67.1 & 22.1 & ND \\
\hline 6.08 & 62.4 & 27.8 & 11.7 & 36.7 & 13.1 & 49.2 \\
\hline 0.76 & ND & ND & ND & ND & ND & ND \\
\hline 1.74 & ND & 1.80 & 1.52 & 1.41 & 1.62 & ND \\
\hline ND & ND & ND & ND & ND & ND & ND \\
\hline 0.96 & ND & 1.62 & ND & 2.16 & 1.70 & ND \\
\hline ND & ND & ND & ND & ND & ND & ND \\
\hline 1.04 & ND & 1.59 & ND & ND & 1.22 & ND \\
\hline ND & ND & ND & ND & ND & ND & ND \\
\hline ND & ND & 2.62 & ND & 7.72 & ND & ND \\
\hline
\end{tabular}

tection limits

but may be unregulated at that level 


\section{Distribution List}

(Page 1 of 2)

Copies

DOE/Nevada Operations Office

Technical Information Resource Center

P.O. Box 98518

Las Vegas, Nevada 89193-8518

Mr. Paul J. Liebendorfer

1 (2 Uncontrolled)

Nevada Division of Environmental Protection

Carson City, Nevada

Mr. Jon Taylor

1

Nevada Division of Environmental Protection

Carson City, Nevada

Nevada Division of Environmental Protection

Las Vegas, Nevada

Ms. Sabine T. Curtis

1 (5 Uncontrolled)

Acting Industrial Sites Subproject Manager

DOE/Nevada Operations Office

Mr. Ed Thomas

IT Corporation

Las Vegas, Nevada

Mr. Don Cox

IT Corporation

Las Vegas, Nevada

Mr. Richard A. Dubiskas, Technical Lead

IT Corporation

Las Vegas, Nevada 


\section{IVistribution List}

(Page 2 of 2)

\section{Copies}

Mr. Ken Beach, Project Manager

IT Corporation

Las Vegas, Nevada

Mr. Michael Brown

IT Corporation

Las Vegas, Nevada

Ms. Angelica Russell

Central Files

IT Corporation

Las Vegas, Nevada

Ms. Cindy Dutro

IT Corporation

Las Vegas, Nevada

Ms. Jeanne Wightman

IT Corporation

Las Vegas, Nevada 